Terr. Atmos. Ocean. Sci., Vol. 17, No. 4, 615-644, December 2006

\title{
Distribution and Characters of Gas Hydrate Offshore of Southwestern Taiwan
}

\author{
Char-Shine Liu ${ }^{1, *}$, Philippe Schnürle ${ }^{1}$, Yunshuen Wang ${ }^{2}$, \\ San-Hsiung Chung ${ }^{2}$, Song-Chuen $\mathrm{Chen}^{2}$, and Ta-Hen Hsiuan ${ }^{3}$
}

(Manuscript received 31 October 2005, in final form 28 April 2006)

\begin{abstract}
Bottom simulating reflector (BSR) is a key indicator for the presence of gas hydrate beneath the sea floor. Widely distributed BSRs have been observed in the area offshore of southwestern Taiwan where the active accretionary complex meets with the passive China continental margin. In order to better understand the distribution and characters of the gas hydrate in the region, closely spaced $(1.86-\mathrm{km}$ line spacing) multichannel seismic reflection surveys have been conducted in recent years under the support of the Central Geological Survey, ROC. Over $10000 \mathrm{~km}$ of multichannel seismic reflection profiles have been collected that cover an area of about $10000 \mathbf{~ k m}^{2}$ offshore of southwestern Taiwan. BSRs can be identified along $50 \%$ of the seismic profiles that we collected. A newly compiled BSR distribution map suggests that gas hydrates are distributed both in the passive margin of the China continental slope as well as in the submarine Taiwan accretionary wedge, from water depths of 500 to over $3000 \mathrm{~m}$. Gas hydrates are most concentrated underneath anticlinal ridges in the accretionary wedge, and underneath the slope ridges of the passive continental margin that were formed due to sedimentary processes. Active fluid activities are evident from various features observed on seismic reflection and chirp sonar profiles, such as mud volcanoes, gas plumes and gas charged shallow sedimentary layers. Fluid migration model has been established from a set of pseudo 3D seismic reflection data. The predicted locations of high fluid
\end{abstract}

\footnotetext{
${ }^{1}$ Institute of Oceanography, National Taiwan University, Taipei, Taiwan, ROC

2 Central Geologic Survey, Taipei, Taiwan, ROC

${ }^{3}$ Exploration Department, Chinese Petroleum Company, Miaoli, Taiwan, ROC

* Corresponding author address: Prof. Char-Shine Liu, Institute of Oceanography, National Taiwan University, Taipei, Taiwan, ROC; E-mail: csliu@ntu.edu.tw
} 
flux correlate well with those interpreted from geochemical analyses that show very high methane concentrations and very shallow sulfate-methane interfaces (SMI). This demonstrates the importance of structural control over gas hydrate emplacement. From the observed gas hydrate distribution and characters, the area offshore of southwestern Taiwan provides an ideal place to study and compare the formation and migration of gas hydrates under different tectonic settings.

(Key words: Gas hydrates, Bottom simulating reflectors, Marine seismic reflection data, Passive and convergent boundary, Southwestern Taiwan)

\section{INTRODUCTION}

Gas hydrate is a solid crystalline material composed of a gas molecule enclosed by a cage of water molecules (called a clathrate) (Sloan 1998). Natural gas could form gas hydrate in high pressure and low temperature environments where gas and water supplies are sufficient. Natural occurrences of gas hydrates have been reported world wide in high latitude areas beneath permafrost, in the sediment of continental slopes of both passive and active continental margins, and in deep-water sediment of inland seas and lakes (see Kvenvolden and Lorenson 2001). Since there are enormous amount of gases (mostly methane) trapped in hydrate form and stored in marine sediment and in polar regions, gas hydrate has been suggested as a potential source for future energy (e.g., Kevenvolden 1998; Collett 2004; Johnson and Max 2006), a trigger for global climate changes (e.g., Kennett et al. 2003; Dickens 2004) and seafloor instability and geohazards (e.g., Dillon et al. 2001; Best et al. 2006).

Among various techniques and proxies used for gas hydrate detection in marine sediment, bottom-simulating reflector (BSR) is the most widely used one. A BSR is a seismic reflection sub-parallel to the sea floor topography but with reversed polarity compared to that of the sea floor reflection (Shipley et al. 1979). It appears on a seismic reflection profile where hydratebearing sediment lies above sediment containing some free gases (Tucholke et al. 1977), and has been regarded as the base of the gas hydrate stability zone (Stoll et al. 1971; Hyndman et al. 1992). Though BSR has been used to map gas hydrate distributions in the continental margins around many parts of the world since the 1970s, it was not until early 1990s that Reed et al. (1991, 1992) first reported the observation of BSR in the area offshore of southern Taiwan. Huang (1993) and Chang (1993) later reported the existence of BSRs in areas offshore of southwestern (SW) Taiwan. Chi et al. (1998) compiled the first BSR distribution map off southern Taiwan which showed that BSRs are widely present along the trench-ward slope of the southern Taiwan accretionary wedge covering an area over $20000 \mathrm{~km}^{2}$, while Shyu et al. (1998) presented heat flow studies in the area offshore of southern Taiwan where BSRs are present. Further investigation by Liu et al. (1999) and Schnürle et al. (1999) revealed that clear and bright BSRs are widely observed in the area offshore of SW Taiwan where gas hydrates may have economic value due to their dense distribution and proximity to the island of Taiwan. Chow et al. (2000) presented BSR characteristics near mud diapirs, while McDonnell et al. 
(2000) suggested that gas hydrate is probably extensively developed in the region offshore of SW Taiwan because of the suitable tectono-sedimentary environment.

In order to better understand the distribution and characteristics of gas hydrate in the area offshore of SW Taiwan, and to identify potential prospects for future gas hydrate energy resource development, pilot gas hydrate investigation programs were conducted in 2002 and 2003 with support from the Chinese Petroleum Company and the Central Geological Survey, respectively. Multichannel seismic (MCS) data with line spacing of about $1.8 \mathrm{~km}$ have been collected in the offshore area of SW Taiwan, and BSRs are observed almost continuously along the MCS profiles where water depths are greater than $800 \mathrm{~m}$ (Liu et al. 2003).

\subsection{CGS Gas Hydrate Investigation Program}

With the encouraging results of the pilot investigations, the Central Geological Survey (CGS) of the Ministry of Economic Affairs, Taiwan, ROC, launched a comprehensive 4-year gas hydrate investigation program in 2004 that includes marine geophysical, geological and geochemical investigations, lab experiments, gas hydrate database management and international cooperative research.

In the past 3 years, various marine geophysical exploration techniques have been used to map the gas hydrate distribution in the area offshore of SW Taiwan, to understand the regional structures and deposition environment, to investigate the characteristics of the gas hydrate bearing sediment, and to estimate the amount of gas hydrate in place and its energy resource potential. Regional geophysical reconnaissance surveys were conducted to map the regional gas hydrate distribution. Compilation and analyses of geophysical and geological data have been carried out to establish the regional geophysical characters, geological structures, and sedimentary patterns of both the accretionary wedge province and the passive China continental slope regions of the investigation area. Special geophysical investigation techniques, such as 2.5-D (or pseudo 3-D) seismic surveys, ocean bottom seismometers (Cheng et al. 2006; Schnürle et al. 2006), heat flow measurements (Shyu et al. 2006), deep-tow magnetic survey, etc., have been conducted. Regional sedimentary deposition processes (Yu and Huang 2006) and structural patterns have been proposed.

On the geological and geochemical investigation side, over 100 box core samples and over 60 piston core samples (including 4 giant piston cores) have been collected in the past 3 years. Geological and geochemical characteristics of the cored sediments have been investigated, they include: grain sizes, mineral components and physical properties of the sediments and clay mineral distribution (Jiang et al. 2006), $\mathrm{SO}_{4}^{2-}, \mathrm{Cl}^{-}$, organic carbon and sulfide distribution in the sediments (Lin et al. 2006), salinity and $\mathrm{CH}_{4}$ concentration in the bottom water and $\mathrm{CH}_{4}$ and carbon isotopic composition of the pore-space gases of cored sediments (Chuang et al. 2006; Yang et al. 2006), B and $\mathrm{Cl}$ isotopes in the pore waters (Chao and You 2006), and magnetic properties of magnetic minerals in the sediments (Horng and Chen 2006). Methanederived authigenic carbonate with highly depleted carbon isotope values (-54 to $-43 \%)$ have been found both on and offshore of SW Taiwan (Huang et al. 2006). Thus, though no gas hydrate sample has been recovered from the seafloor yet, results from both geophysical and geochemical investigations strongly suggest the existence of gas hydrate off SW Taiwan. 


\subsection{Objectives of This Paper}

This paper summarizes the seismic investigation results of the CGS gas hydrate investigation program. A new BSR distribution map is presented that reveals the wide distribution of gas hydrate in the investigation area. This paper also gives an overview on the geological background and present knowledge on the geophysical and geochemical characteristics of gas hydrates offshore of SW Taiwan. Finally, we discuss the significance of gas hydrate investigation in this region, as this region may be an ideal natural laboratory for understanding the formation, migration, accumulation, and energy resource potential of gas hydrate in a marine environment.

\section{GEOLOGICAL BACKGROUND}

The island of Taiwan is an active mountain belt formed by the collision of the Luzon volcanic arc with the passive China continental margin (Bowin et al. 1978; Ho 1986; Teng 1990; Huang et al. 2000). The offshore area south of Taiwan is an area where the Luzon subduction system transforms into an incipient arc-continent collision system from south to north, as the Luzon subduction complex encroaches on the passive China continental margin off SW Taiwan (Lundberg et al. 1992, 1997; Reed et al. 1992; Huang et al. 1992, 1997; Liu et al. 1997). Distinctive morphotectonic features in the area offshore of southern Taiwan reflect the transition from subduction to collision (Liu et al. 1998). South of about $21^{\circ} 20^{\prime} \mathrm{N}$, the Manila Trench, Hengchun Ridge (accretionary wedge), North Luzon Trough (forearc basin) and Luzon Arc (volcanic arc) consist of major morphotectonic units in the subduction system (Fig. 1). This simple oceanic subduction configuration evolves into an incipient arc-continent collision north of about $21^{\circ} 30^{\prime} \mathrm{N}$, and arc-continent collision on land Taiwan, as the passive China continental margin enters the subduction system obliquely.

\subsection{Morphotectonic Features}

Due to the influx of the orogenic sediment from the Taiwan mountain belt, the width of the N-S trending Hengchun Ridge, or the accretionary wedge, increases from about $70 \mathrm{~km}$ at $20^{\circ} \mathrm{N}$ to over $110 \mathrm{~km}$ near the southern tip of Taiwan (Figs. 1, 2). Morphotectonic expressions are quite different in the frontal portion (the trench side) of the accretionary wedge than that in the rear (the arc side) of the wedge. East of the Hengchun Ridge, the North Luzon Trough is closed north of $21^{\circ} 20^{\prime} \mathrm{N}$, as the forearc basin strata were thrust over the arc basement due to northeastward advance of the back thrusts along the rear of the accretionary wedge (Lundberg et al. 1997; Huang et al. 1997). A small suture basin was formed between the Hengchun Peninsula (the southern end of the Central Ridge) and the Huatung Ridge (uplifted forearc basin material). The forearc basin becomes a narrow trough (the Taitung Trough) lying on top of the Luzon Arc basement east of the Huatung Ridge (Fig. 1). The morphological expressions, structural characteristics and tectonic evolution of the incipient arc-continent collision zone offshore of southeastern Taiwan have been reported extensively (e.g., Chen and Juang 1986; Chen et al. 1988; Huang et al. 1992, 1995, 1997; Lundberg et al. 1992, 1997; Fuh et al. 1997; Liu et al. 1998; Malavieille et al. 2002). 


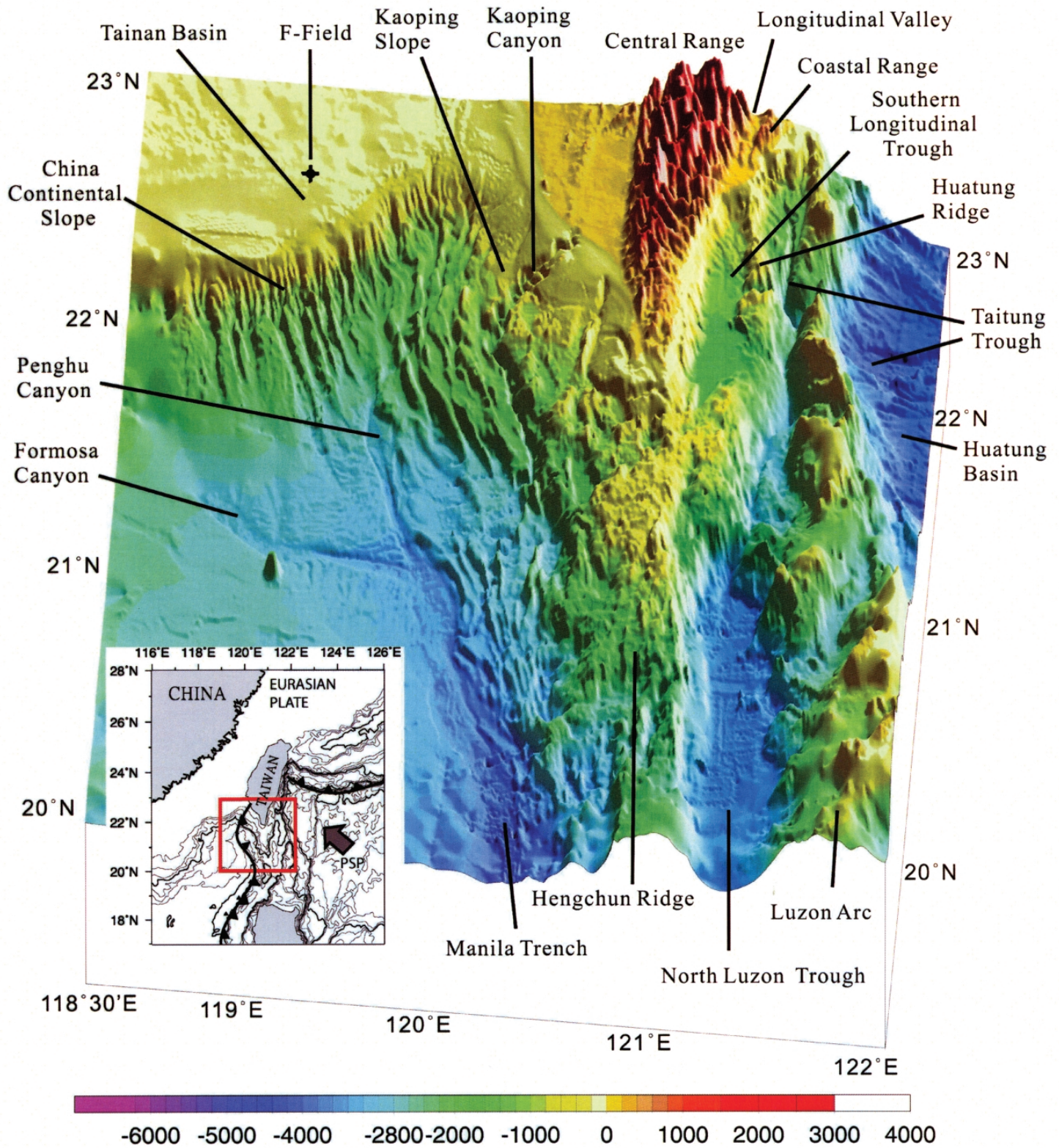

Fig. 1. Shaded-relief of the seafloor topography off southern Taiwan. Red box in inlet shows the map area. Arrow in inlet indicates the convergent direction between the Philippine Sea Plate (PSP) and Eurasian Plate. + shows the location of the F-Field, a gas field under developing. 
Offshore of southwestern Taiwan, where the outgrowth of the submarine accretionary wedge extends westward to the China continental slope, prominent morphological features are anticlinal ridges and submarine canyons (Fig. 1). Distinctive fold-and-thrust structures of the convergent zone and horst-and-graben structures of the passive margin are separated by a deformation front (Fig. 2) which extends from the eastern edge of the Manila Trench and Penghu Canyon NNW-ward to the foot of the continental slope, then turns NE-ward across the continental slope and the Kaoping Shelf, and connects to the frontal thrust of the Taiwan mountain belt on land (Liu et al. 1997, 2004). The Kaoping slope (Yu and Wen 1992) is the frontal portion of the submarine incipient collision zone, which is separated from the China continental slope by the Penghu Canyon system (Fig. 1).

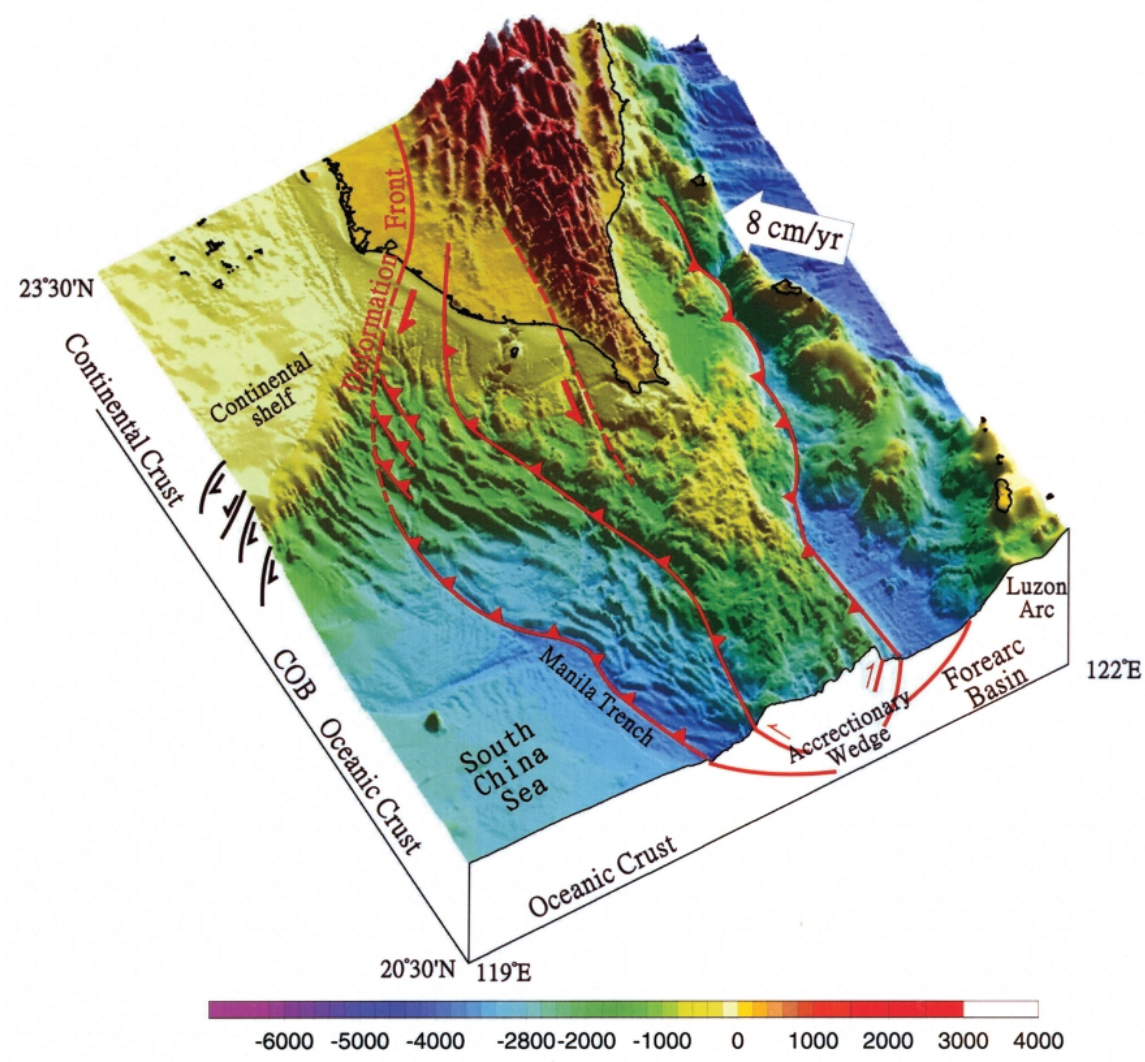

Fig. 2. Tectonic structure of the southern Taiwan offshore area. The three major thrust faults shown as red lines with teeth are, from west to east, the deformation front, the major out-of-sequence thrust that separates the lower slope domain from the upper slope domain of the accretionary wedge, and the back thrust. 


\subsection{Structural Characters}

The submarine accretionary wedge south of Taiwan comprises an active two-sided orogen with its western edge bounded by west-vergent, imbricate thrust ramps over a shallowly eastdipping decollement, and its eastern flank being thrust eastward over the volcanic basement of the Luzon arc (Lundberg et al. 1992; Reed et al. 1992) (Fig. 2). The frontal (trench-side) portion of the accretionary wedge south of Taiwan consists of a lower slope domain characterized by mostly west-vergent ramp anticlines and thrusts, and an intensely deformed upper slope domain (Reed et al. 1992). Seismic reflection profiles running across the frontal part of the accretionary wedge show that different processes govern the structural patterns of the lower slope domain (structural shortening) and the upper slope domain (structural complexity). A prominent out-of-sequence thrust forms the boundary separating these two domains (Fig. 2). This out-of-sequence thrust extends laterally over $250 \mathrm{~km}$ in the offshore region, from south of $20^{\circ} 30^{\prime} \mathrm{N}$ northward to the onshore structure of southwestern Taiwan (Liu et al. 2000). Numerous high-amplitude fault-plane reflections are observed on many of the reflection profiles to the south but are less distinct on the seismic profiles near Taiwan.

Since the gas hydrate investigation area is offshore of SW Taiwan, we focus our attention on the structural features in this area. The southern Taiwan submarine accretionary wedge has developed on top of a pre-existing rift basin, the Tainan basin (Lin et al. 2003). Two tectonic provinces, the active accretionary wedge province and the passive China continental margin province, are separated by a deformation front (Figs. 2, 3). West of the deformation front, Neogene extensional structures prevail and the basin is governed by foreland-type subsidence. The regional structural trend of the normal faults has been suggested to be ENE-WSW (Sun 1982; Hu 1988) or E-W (Yang et al. 1991). East of the deformation front, imbricate fold-andthrust structures are the predominant structural features of the submarine accretionary wedge (Fig. 3). Seismic data reveal that the lower slope domain of the accretionary wedge is characterized by a series of anticlinal ridges generated as fault-bend folds over thrust ramps. Slope basins are pounded behind many of the thrust ridges on the lower slope, and deposition has accompanied the formation of these structures as shown by progressively tilted reflectors in the slope basins (Lundberg et al. 1992). The structure of the wedge changes abruptly at the boundary between the domains of the lower and upper slope. Internal reflections in the upper slope domain are highly discontinuous, implying intense deformation. The increase in surface slope at the boundary suggests significant thickening of the accretionary wedge, probably reflecting out-of-sequence thrusting within the wedge (Reed et al. 1992).

In the nearshore area of the submarine accretionary wedge off SW Taiwan, diapiric ridges were developed beneath thick sedimentary strata (Sun and Liu 1993; Liu et al. 1997). Muddy fluids emitted from active mud diapirs form mud volcanoes on the seafloor (Liu et al. 1997; Chiu et al. 2006). Most of the diapiric ridges trend in NNE-SSW direction, parallel to the structural trend of the folds and thrust faults and mud volcanoes on land Taiwan (Yang et al. 2004), and many diapiric ridges connect to anticlinal structures on land SW Taiwan (Huang 1995; Chuang 2006).

\subsection{Sedimentary Processes}

The sedimentary framework of SW Taiwan and the offshore area has been described by 


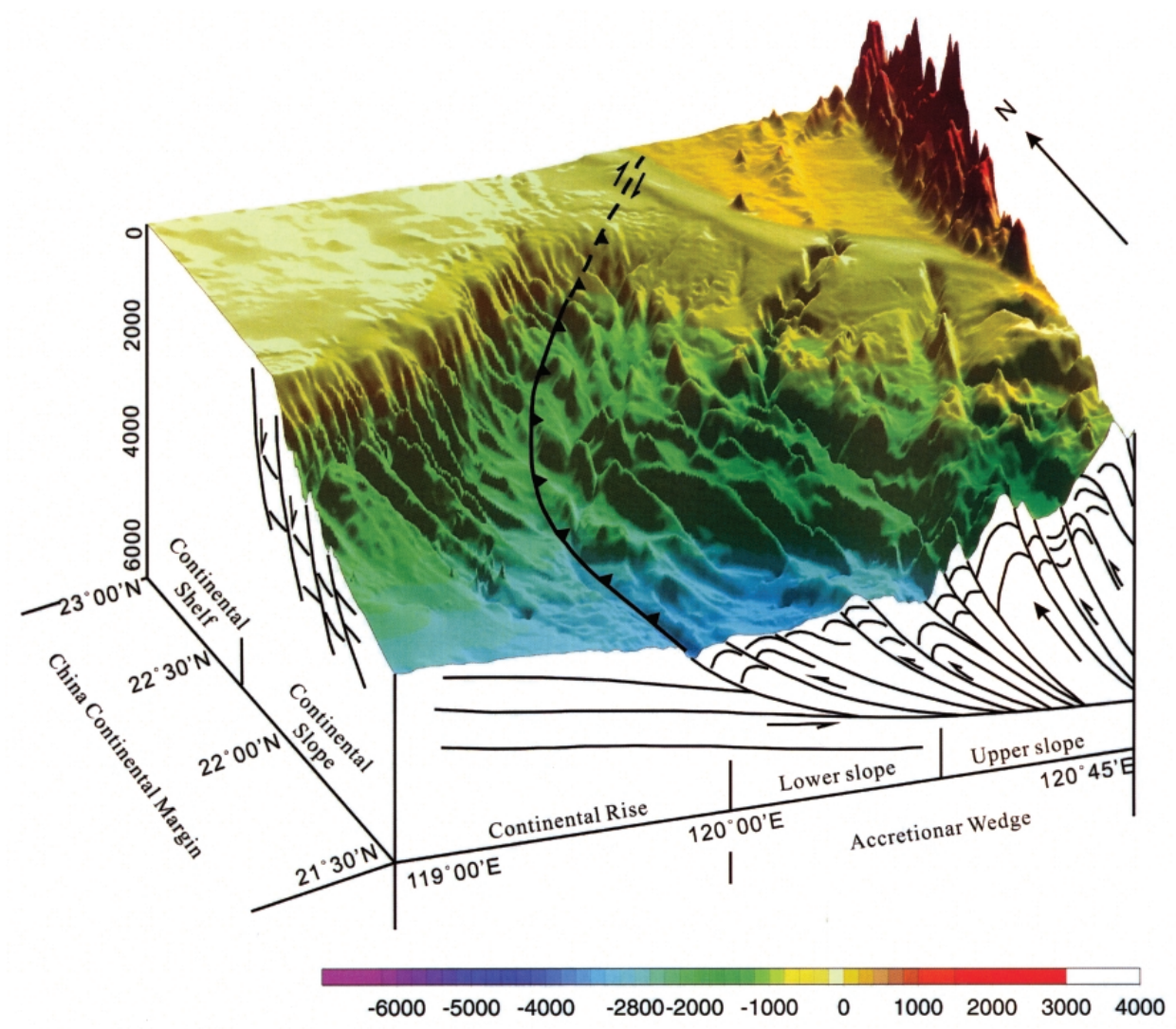

Fig. 3. 3-D view of the structure features off SW Taiwan. Curved black line with teeth marks the location of the deformation front (Modified from Liu et al. 1997).

Chiang et al. (2004). Sedimentary facies show lateral variations from extreme coarseness of fluvial conglomerates proximal to the topographic front onshore of SW Taiwan to fine-grained deep marine mud close to the deformation front. Much of the recent orogenic sedimentation south of Taiwan occurs as turbidite deposition of sand-rich detritus via gravity flows, directed along several submarine canyon and channel systems into a complex system of sedimentary basins, while background sedimentation of hemipelagic mud out of suspension occurs between turbidite events (Lundberg et al. 1992). Offshore of SW Taiwan, there are two major submarine canyon systems: the Penghu Canyon and the Kaoping Canyon systems, plus numerous small submarine canyons and channels (Fig. 1). These submarine canyons crosscut the strong morphologic fabric of the accretionary wedge, and are the main conduits of the orogenic sediment transported from the Taiwan mountain belt to the South China Sea basin. At 
present, the major depocenter of sediment transported by the Kaoping and Penghu canyon systems is the Manila Trench, while various slope basins form smaller depocenters. Sedimentation in the slope basins has continued throughout uplift of the anticlinal ridges, resulting in formation of asymmetrical wedges of growth strata that are imaged as progressively tilted reflectors on seismic profiles (Lundberg et al. 1992). Modal analyses of sand samples from piston cores collected off SW Taiwan confirm that the major sediment input to the accretionary wedge province is from Taiwan, dominated by sedimentary lithic fragments and lowgrade metamorphic lithic fragments, though in the main depocenter (i.e., the Manila Trench and adjacent South China Sea basin), minor but important amounts of sediment come from China (Yen and Lundberg 2006).

West of the deformation front, Pleistocene-Quaternary sediment of the China continental margin form the uppermost part of the South China Sea shelf and slope. Numerous submarine canyons and channels developed at the shelf edge head down-slope in a SE direction, and carry shelf sediment from China into the lower slope and continental rise. Mass wasting is the dominant sedimentary process on the steep continental slope. Land slides and debris aprons can be recognized on the bathymetry map as they form slope ridges on the lower slope area (Fig. 1). Yan et al. (2006) suggested that the largest submarine landslide of the South China Sea occurred in this region near our investigation area.

\section{SEISMIC SURVEY}

\subsection{Seismic Investigation}

Seismic reconnaissance surveys for gas hydrate investigation have been carried out since 2002 using a high-resolution multichannel seismic (MCS) reflection system aboard R/V Ocean Researcher I (OR1). A 24- or 48-channel solid streamer with 12.5-m channel interval was used to receive seismic signals, and the seismic source was an airgun array consisting of 3 Bolt airguns with a total volume from 475 to $775 \mathrm{in}^{3}$ (depending on the size of the airguns used in different cruises). The firing rate was $10 \mathrm{sec}$ giving a nominal shot interval of $25 \mathrm{~m}$. Seismic surveys were designed to collect parallel lines that run across the structural trend with line spacing of about $1.86 \mathrm{~km}$ (1 arc min.). Over $10000 \mathrm{~km}$ of MCS profile data have been collected to map the BSR distribution in the investigation area (Fig. 4).

In addition to the 2-D MCS reconnaissance surveys, 2.5-D MCS surveys have been conducted at 3 selected blocks in the investigation area where BSRs are densely distributed (Fig. 4). These datasets were collected using the high-resolution MCS system described above but with 400- to 250-m line spacing. OBSs were deployed along key profiles during each of the 32.5 -D MCS surveys to provide velocity constrains (e.g., Cheng et al. 2006), and to derive S-wave velocity information (Schnürle et al. 2006). Further analyses of these 2-D MCS/OBS experiments will be published later.

Besides the high-resolution MCS data mentioned above, large-offset seismic reflection data collected previously have also been used in this study. Those datasets include 160-channel deep seismic profiling data of EW9509 (using a 20-gun array with a total volume of $8420 \mathrm{in}^{3}$ as seismic source) collected by the R/V Maurice Ewing, 56-channel seismic reflection data of 
MCS367 and MCS423 collected by the R/V OR1, and many other 24- and 6-channel seismic data from previous cruises. The large offset seismic data enabled us to perform attribute analyses (e.g., Schnürle et al. 1999), while detailed velocity information have been derived from one of the EW9509 profiles (EW9509-33) that also has OBSs deployed (Schnürle et al. 2002, 2004).

All the MCS data used in this study were processed at the Institute of Oceanography, National Taiwan University using the ProMAX and the SIOSEIS seismic data processing systems. The typical seismic data processing sequence used comprises trace editing, spiking noise removal, water column mute, geometry set up, amplitude compensation, predictive

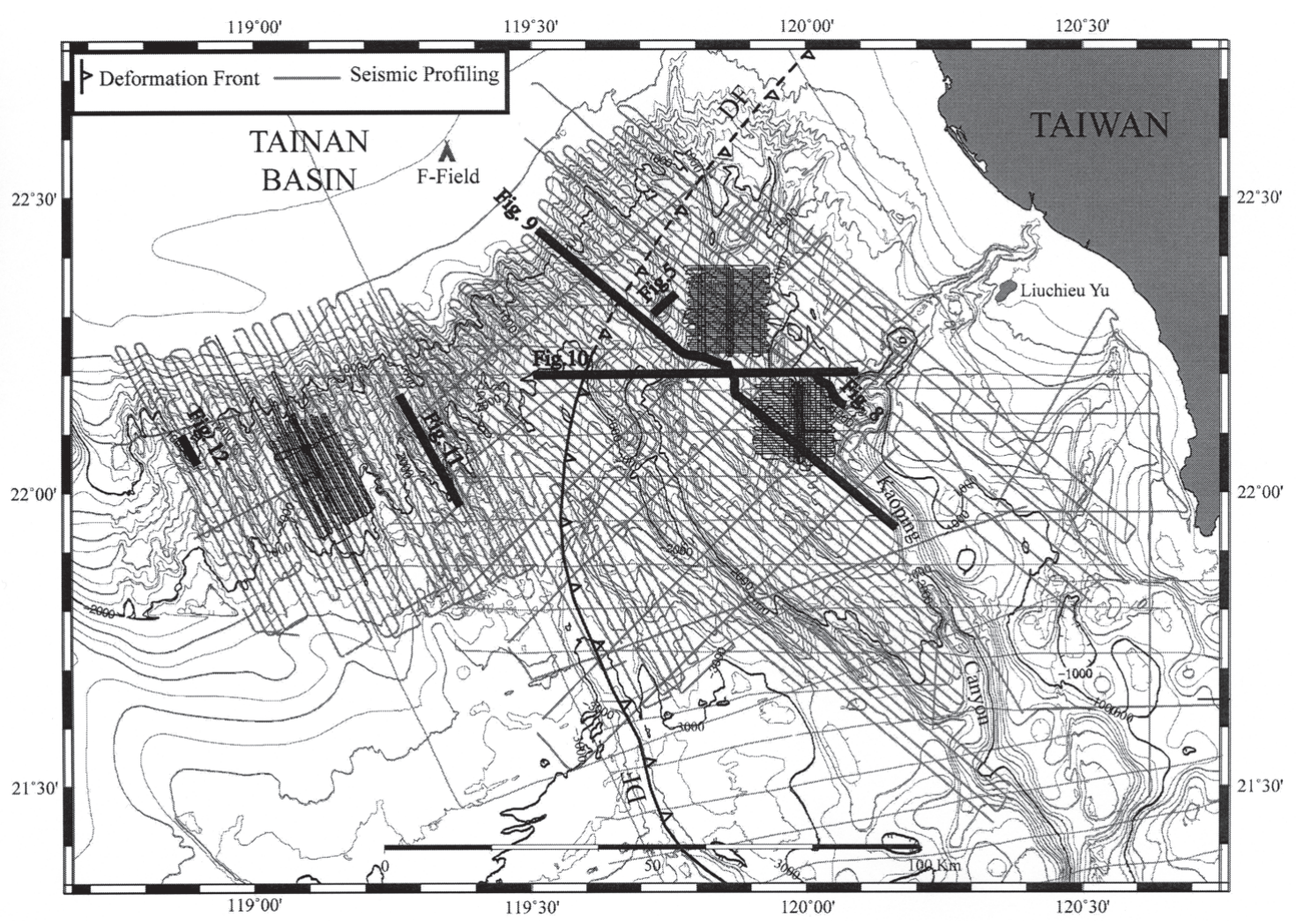

Fig. 4. Seismic survey tack plot. Thin lines are seismic profile locations, three 2.5-D survey areas are shown as closely spaced ship track blocks. Thick lines show the locations of the seismic profiles appearing in figures annotated. Curved line with teeth marks the deformation front. Bathymetry contour interval is $100 \mathrm{~m}$. 
deconvolution, band-pass filtering, velocity analysis (not on short offset high-resolution MCS data though), normal move-out correction, stacking, and constant velocity $\left(1500 \mathrm{~m} \mathrm{~s}^{-1}\right) \mathrm{F}-\mathrm{K}$ time migration. For the short offset (maximum offset is only $700 \mathrm{~m}$ ) high-resolution MCS data, the normal move-out velocities are based on a velocity versus sub-bottom depth function of Hamilton (1980) for active margins: $\mathrm{V}_{\text {avg }}(\mathrm{t})=1511+1041 \times \mathrm{t}-372 \times \mathrm{t}^{2}$, where $\mathrm{t}$ is the one-way travel time below the sea-floor. The conversion to sub-bottom depth is given as $\mathrm{z}(\mathrm{t})=\mathrm{t} \times \mathrm{V}_{\mathrm{avg}}(\mathrm{t})$. This relationship was used in previous BSR distribution studies offshore of southern Taiwan (Chi et al. 1998; Schnürle et al. 1999), and is in good accordance with the sub-bottom velocities obtained from the first-arrival tomographic inversion of the OBS data collected in this area.

\subsection{Sub-Bottom Profiling}

Underway $3.5 \mathrm{kHz}$ (before year 2001) and chirp sonar (after 2002) sub-bottom profile data have been collected during most of the seismic cruises. Digital $38 \mathrm{kHz}$ echo sounding profiles have also been recorded since 2004. These datasets provide very high-resolution images of sea floor profiles and shallow (few tens of meters to over $100 \mathrm{~m}$ ) sedimentary layers. Many gas hydrate related features, such as gas plumes, mud volcanoes and gas-charged sediment have been observed on these datasets (Chiu et al. 2006), and will be discussed in later sections.

\section{BSR DISTRIBUTION AND SEISMIC CHARACTERISTICS}

\subsection{BSR Distribution}

Over $10000 \mathrm{~km}$ of MCS profile data in the investigation area (Fig. 4) have been examined to identify BSRs on the seismic sections. Clear BSRs are observed along many parts of the seismic profiles. BSR is best recognized where it cross-cuts the dipping sedimentary strata and extends laterally sub-parallel to the seafloor topography (Fig. 5). Amplitude blanking is commonly observed above the BSR, while below the flanks of an anticlinal ridge, high amplitude and low frequency reflections beneath the BSR are often present (Fig. 5). The blanking (or whitening) effect has been attributed to the presence of gas hydrate in the sedimentary strata above the BSR, but may as well reflect areas of naturally low and uniform reflectance (Holbrook et al. 1996), and has not been directly and unambiguously attributed to the occurrence of gas hydrate (Vanneste et al. 2000). On the other hand, the strong reflections beneath the BSR are common features of free gas accumulation beneath a gas hydrate-bearing layer (e.g., Singh and Minshull 1994; Wood et al. 1994), and have been correlated to the presence of free gas at drilling sites (e.g., Bangs et al. 1993; Holbrook et al. 1996; Wood and Ruppel 2000).

We have digitized all BSRs identified from our seismic data volume, and computed the BSR sub-bottom depths using the Hamilton (1980) velocity-depth relationship described earlier in Section 3.1. Figure 6 presents the most up-dated BSR distribution that we have compiled. In general, BSRs are distributed widely in the investigation area, from the accretionary wedge province to the passive China continental margin province. BSRs appear beneath the seafloor of water depth as shallow as $500 \mathrm{~m}$ in the upper continental slope of the passive China con- 


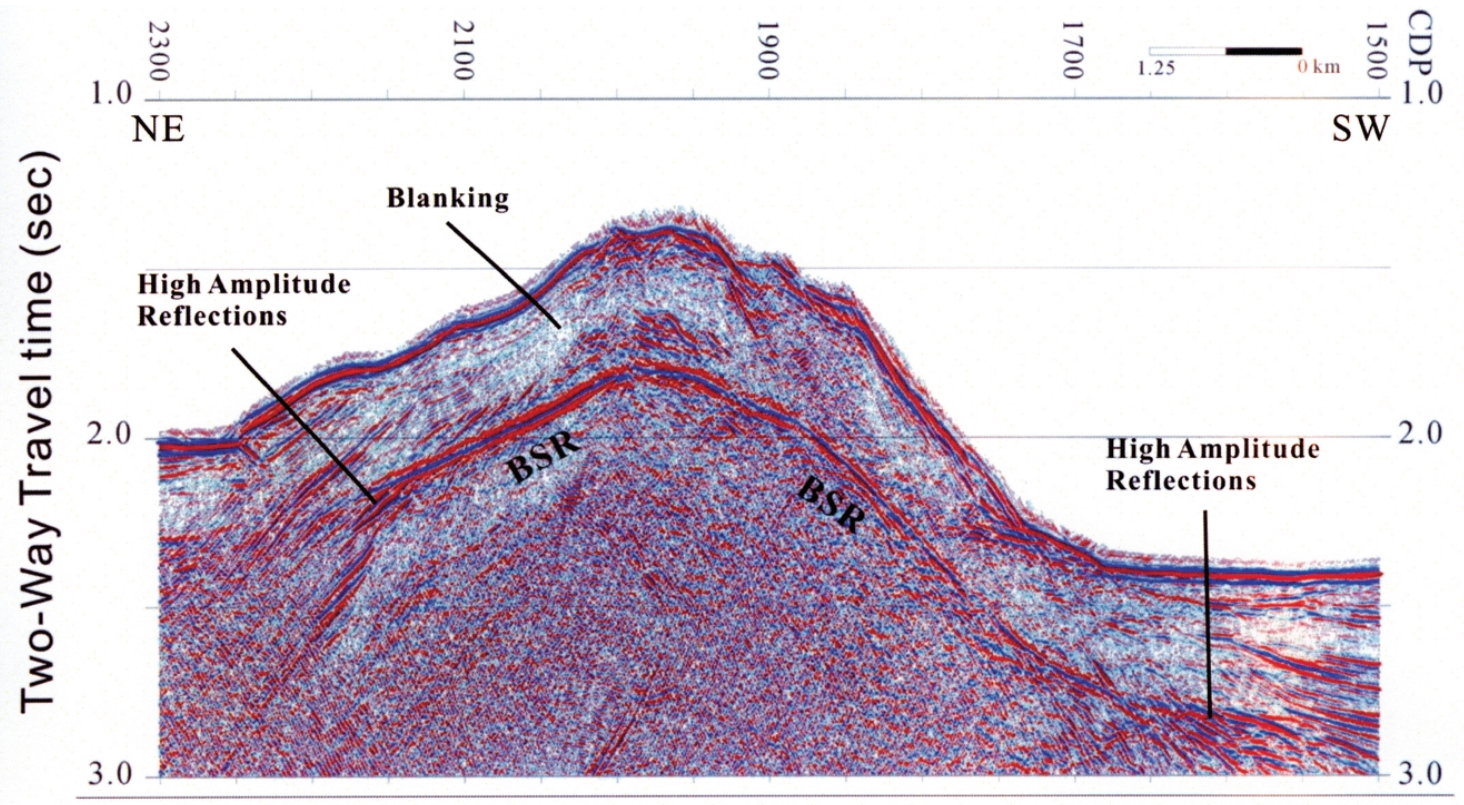

Fig. 5. An example of a bottom simulating reflector (BSR) in the offshore area of southwestern Taiwan. Blanking zone (white zone) above the BSR and high-amplitude reflections beneath the BSR are all clearly shown.

tinental margin, to over $3000 \mathrm{~m}$ in the Manila Trench area. BSRs are mostly concentrated west of the Kaoping Canyon, and extend almost continuously to the continental slope of the passive China continental margin. There is no apparent change on the BSR distribution characters across the deformation front (Fig. 6).

The BSR sub-bottom depth in general correlates positively with the seafloor depth, but also shows local variations at some places (Fig. 7). Assuming that the BSR marks the bottom of the gas hydrate stability zone, we can calculate the gas hydrate stability curves as a function of the BSR sub-bottom depth versus water depth for hydrostatic or lithostatic pressure conditions. For a given water depth $y$, the pressure at the BSR sub-bottom depth $x$ is given by: $\mathrm{P}=\rho_{\mathrm{w}} \mathrm{g} y+\rho \mathrm{g} x+\mathrm{P}_{0}$, where $\mathrm{P}_{0}$ is the atmospheric pressure, $\rho_{\mathrm{w}}$ is the density of water and $\rho$ the density of the water (for hydrostatic conditions) or sediments (for lithostatic conditions) above the BSR. The temperature at the BSR is: $\mathrm{T}_{\mathrm{bsr}}=\mathrm{m} /\left[\mathrm{b}-\ln \left(\rho_{\mathrm{w}} \mathrm{g} y+\rho \mathrm{g} x+\mathrm{P}_{0}\right)\right]$, where $\mathrm{m}=33.4$ and $\mathrm{b}=8245$ below $286.15^{\circ} \mathrm{K}$, and $\mathrm{m}=41.636$ and $\mathrm{b}=10602$ above $286.15^{\circ} \mathrm{K}$ (Gayet et al. 2005). Assuming a constant temperature $\mathrm{T}_{0}=275.85^{\circ} \mathrm{K}$ at the seafloor, and conductivity $\mathrm{K}=1.0 \mathrm{~W} \mathrm{~m}^{\circ} \mathrm{K}^{-1}$ within the sediments above the BSR, a set of methane hydrate stability curves are generated for heat flow values Q ranging from 25 to $75 \mathrm{~mW} \mathrm{~m}^{-2}$ (Fig. 7), 


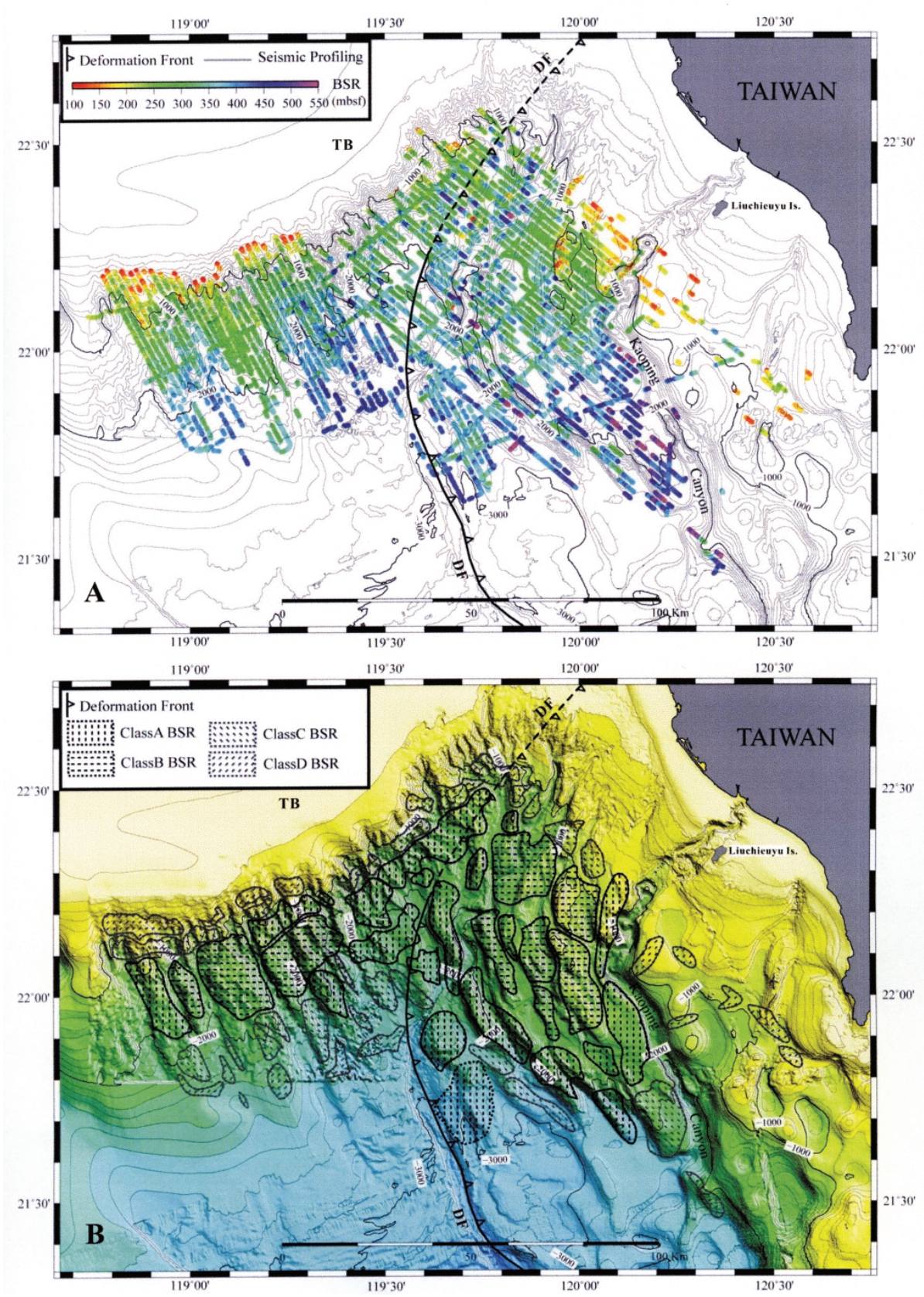

Fig. 6. BSR distribution maps. A. Locations of BSR identified along seismic profiles. Color indicates BSR sub-bottom depth. B. BSR distribution grouped by the quality of BSR appearance. Class A and Class B BSRs are identified with high confidence, Class $\mathrm{C}$ is probably a BSR and Class D is a probable BSR. DF: deformation front. TB: Tainan Basin. 


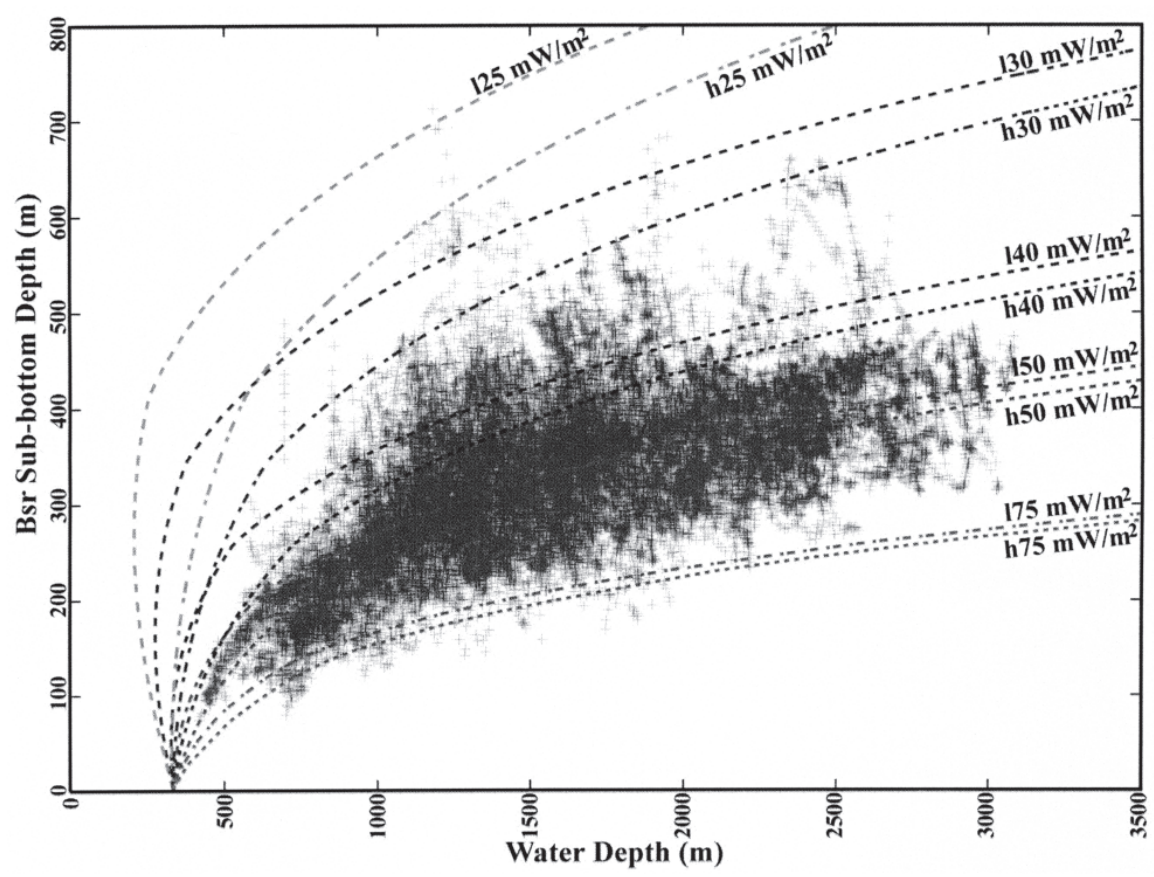

Fig. 7. Water depth vs. BSR sub-bottom depth plot. Dashed curves are the calculated gas hydrate stability curves under lithostatic (expressed as lxx where $\mathrm{xx}$ are heat flow value) and hydrostatic pressure (hxx) conditions for heat flow values of $25,30,40,50$, and $75 \mathrm{~mW} \mathrm{~m}^{-2}$, respectively.

where $\mathrm{Q}$ is given by $\mathrm{Q}=\left(\mathrm{T}_{\mathrm{bsr}}-\mathrm{T}_{0}\right) \times \mathrm{K}_{\mathrm{bsr}} / x$. Based on Fig. 7, the best fit heat flow value $\mathrm{Q}$ is $45 \mathrm{~mW} \mathrm{~m}^{-2}$ under hydrostatic conditions and $50 \mathrm{~mW} \mathrm{~m}^{-2}$ under lithostatic conditions. Both values are lower than the average heat flow value of $64 \mathrm{~mW} \mathrm{~m}^{-2}$ estimated from 23 measurements (Shyu et al. 2006). Though using a different conductivity value could shift the results, further investigations are needed to explain the discrepancy.

Figure $6 \mathrm{~b}$ shows BSR distribution together with seafloor topography. In this figure, BSRs are grouped based on their quality of appearances on seismic profiles. Class A and Class B BSRs are the most clear and have the highest amplitude and high confidence on their identifications on MCS profiles. They appear under the slope ridges of the passive continental margin, and below the anticlinal ridges and adjacent slope basins in the accretionary wedge province. Class C represents probable BSR on seismic profiles. Most of the Class C BSRs appear in places where sedimentary strata are flat, thus it becomes difficult to differentiate BSRs from lithologic reflectors. Class D indicates possible BSR on seismic profiles where the appearance of BSR is week but still exhibits some characters (like high amplitude reflections below). 
Most of the Class D BSRs lie on the upper slope where water depth is less than $1000 \mathrm{~m}$, or on the distal apron of the passive continental slope where reflectors are flat.

Figure $6 \mathrm{~b}$ also reveals that few BSRs are present along submarine canyons and steep fault scarps. This could be due to either the complicated seafloor topography disrupting the reflection signals, or more likely, the sedimentary processes in the submarine canyon and faulting activity having changed the temperature-pressure conditions of gas hydrate formation and consequently causing an escape of free gas into the sea water.

Whether BSRs exist beneath a submarine canyon or across a fault zone may depend on the submarine processes in the canyon and the activity of faults. In a seismic section located at the western bank of the Kaoping Canyon where a gentle fold is present (Fig. 8), a clear BSR has developed that extends laterally over $10 \mathrm{~km}$ below the fold and the adjacent, probably abandoned, submarine canyon. Below the western flank of the fold, bright seismic reflections are present beneath the BSR which suggests gas accumulation. A west-vergent thrust fault can be observed that cross-cuts the west-dipping sedimentary strata and the BSR. This fault may not be active at the present time, as no apparent offset of the seafloor, BSR, and the dipping sedimentary strata can be detected. Bright reflections below the fault plane also indicate that little gas, if any, could escape through this fault. However, gas hydrate or fluid should have filled the fault fracture to provide the needed impedance contrast that produces the clear fault plan reflection.

\subsection{Seismic Characteristics of BSRs}

Figure 9 presents a MCS profile that runs from the passive China continental slope, crosses the deformation front, and extends southwestly across the lower slope domain of the accre-

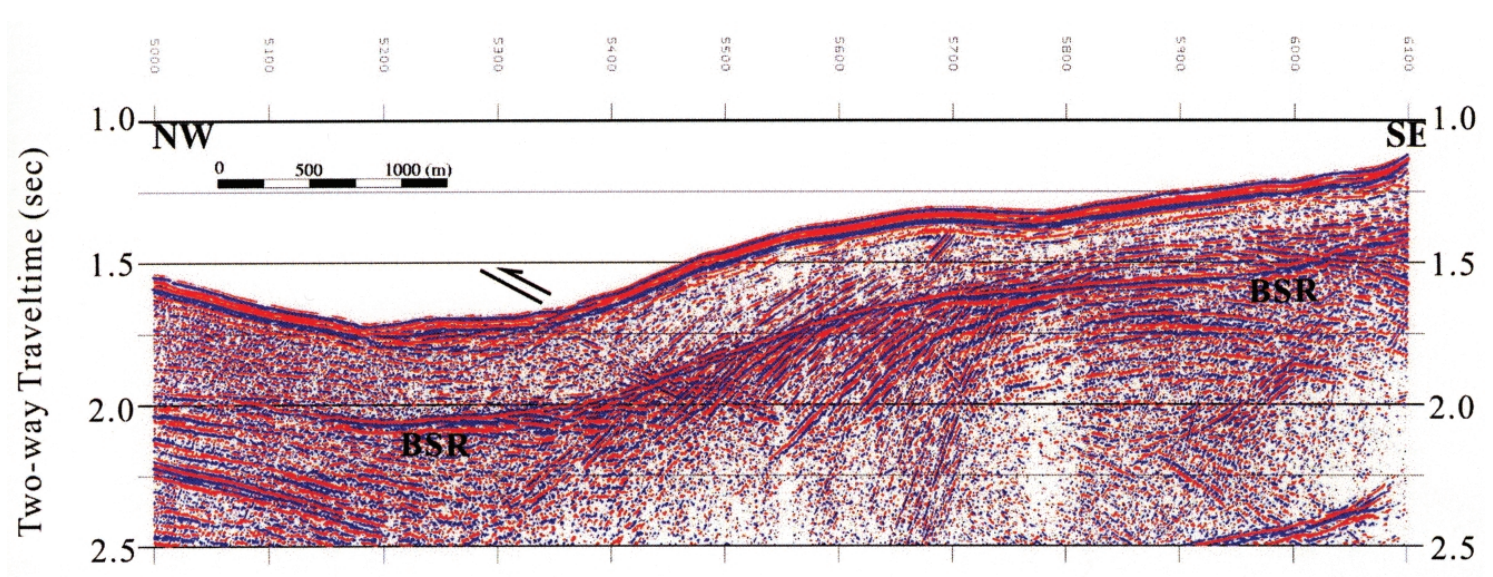

Fig. 8. Migrated seismic section from MCS647-12. A west-vergent thrust fault can be seen cutting across dipping reflections and BSR. See Fig. 4 for profile location. 


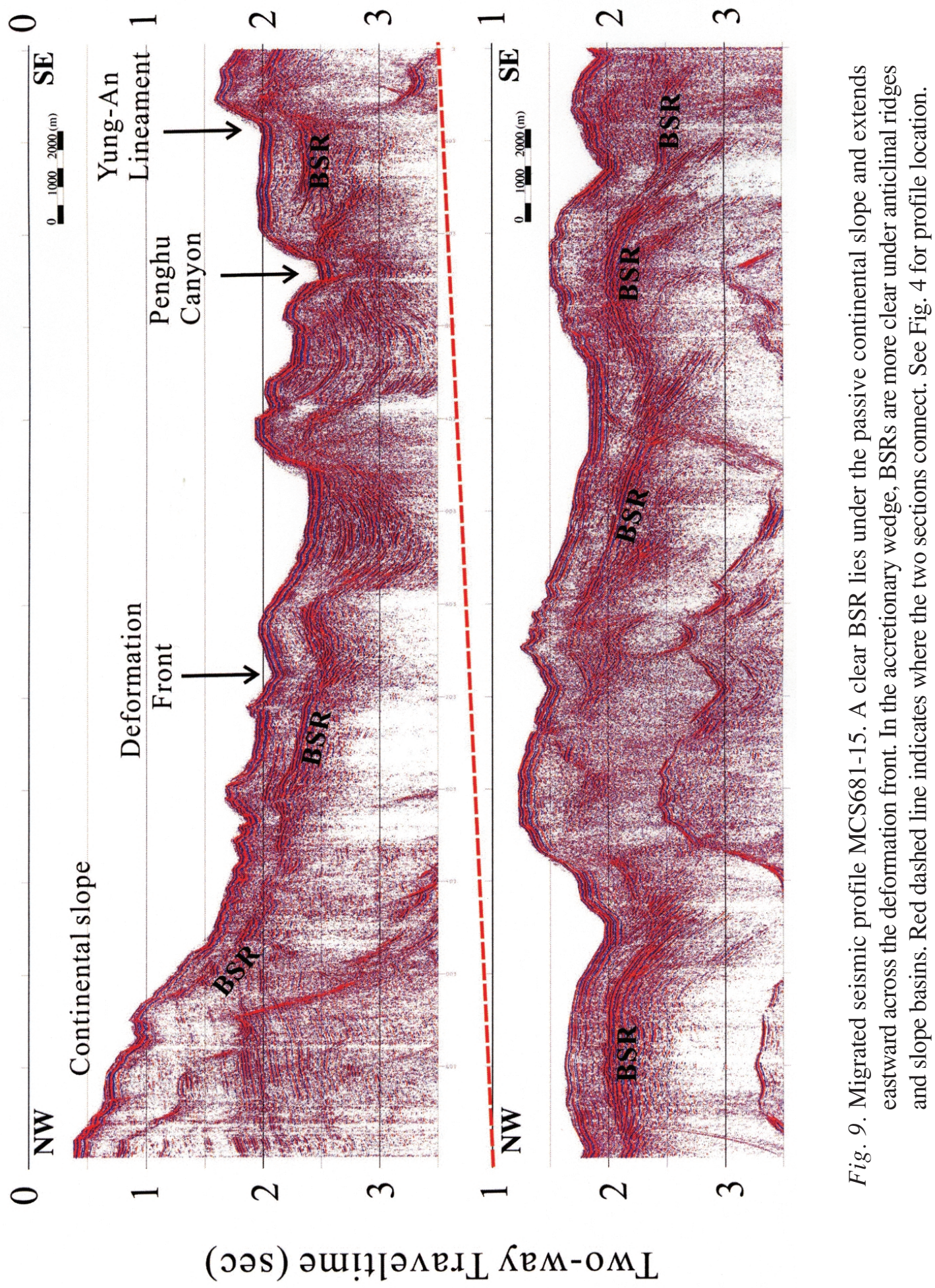


tionary wedge. Clear BSRs are observed along many sections of this profile: BSRs are present more or less continuously under the lower slope of the passive margin, then extend below the deformation front and into the fold-and-thrust belt of the accretionary wedge. In the accretionary wedge, BSRs are well developed under the gentle folds and slope basins, but may disappear under the steep slopes of the western flank of several anticlinal ridges where faults may emerge on the seafloor.

Strong reflections usually exist beneath BSRs under anticlinal ridges and slope basins. Figure 10 shows part of the EW9509-33 profile that runs in an E-W direction across the accretionary wedge. This set of 160-channel large-offset (4000 m maximum offset) seismic data enabled us to derive good velocity information along the profile. A series of Kirchoff prestack depth migrations of the common-offset panels were performed in a layer stripping streamlined Deregowski (1990) loop (Schnürle et al. 2004). The depth section and the correlated migration interval velocity field are shown in Fig. 10. Velocity field profile shows that low velocity zones lie beneath BSRs where high amplitude reflections exist, confirming that free gas exists beneath BSRs there. However, the constraints on the lower bounds of the low velocity zones are rather poor, and a very small amount of free gas in the pore space could generate the high amplitude reflections observed. From combined MCS/OBS data analysis, Schnürle et al. (2004) suggested that the gas hydrate saturation in the sediment layer above BSR is low (0-10\%), and the free gas saturation just below a BSR is in the range of $0-2 \%$.

In the passive margin, BSRs exist mostly under the slope ridges separated by submarine canyons and gullies. Many of the slope ridges may be formed by submarine land slide processes (Fig. 1). Figures 11 and 12 present two examples of the BSR characters under the slope ridges. In Figure 11, a clear BSR extends continuously below the ridge axis for about $5 \mathrm{~km}$. In the same slope ridge, a gas plume that rises over $300 \mathrm{~m}$ above seafloor has been observed on $38 \mathrm{kHz}$ echo sounding profile (S. Lin, personal communication), suggesting high methane flux in this ridge. Figure 12, on the other hand, shows a well developed mud volcano that lies on top of the slope ridge where a strong BSR extends about $3 \mathrm{~km}$ laterally below the seafloor. Chirp sonar and $38 \mathrm{kHz}$ profiles all show fluid activities at this mud volcano (Chiu et al. 2006).

\section{GAS HYDRATE AND FLUID ACTIVITIES}

Seismic reflection data reveal that BSRs are widely as well as densely distributed in the investigation area offshore of SW Taiwan (Fig. 6). In addition, seismic, chirp sonar and $38 \mathrm{kHz}$ echo sounder data all indicate that there are high fluid activities in many places of the investigation area. Figure 13 shows a recent compilation of mud volcanoes on land and offshore of SW Taiwan. Sites where active gas plumes have been observed on $38 \mathrm{kHz}$ or sub-bottom profile data are specified by circle surrounded stars. Submarine mud volcanoes are distributed on both the accretionary wedge and the passive continental margin provinces, and are associated with either diapric ridges, faults and fractures, or gas hydrates (Chiu et al. 2006). The submarine mud volcanoes observed in either the passive continental slope or the deep water area of the accretionary wedge all have BSRs below.

In the nearshore area of the Kaoping slope and Kaoping shelf, though no BSR has been observed due to the shallow water depths, active fluid venting on the seafloor clearly suggests 

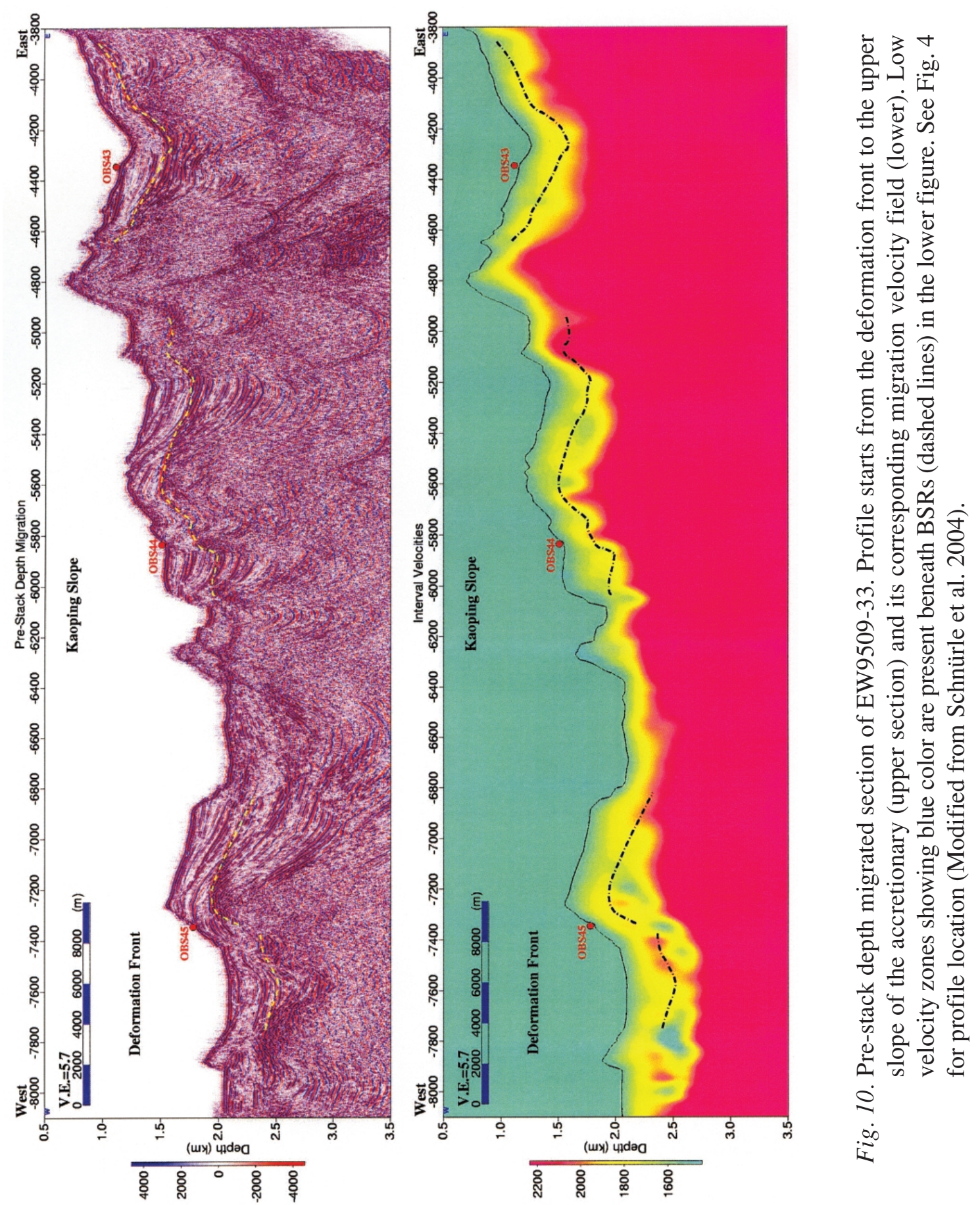


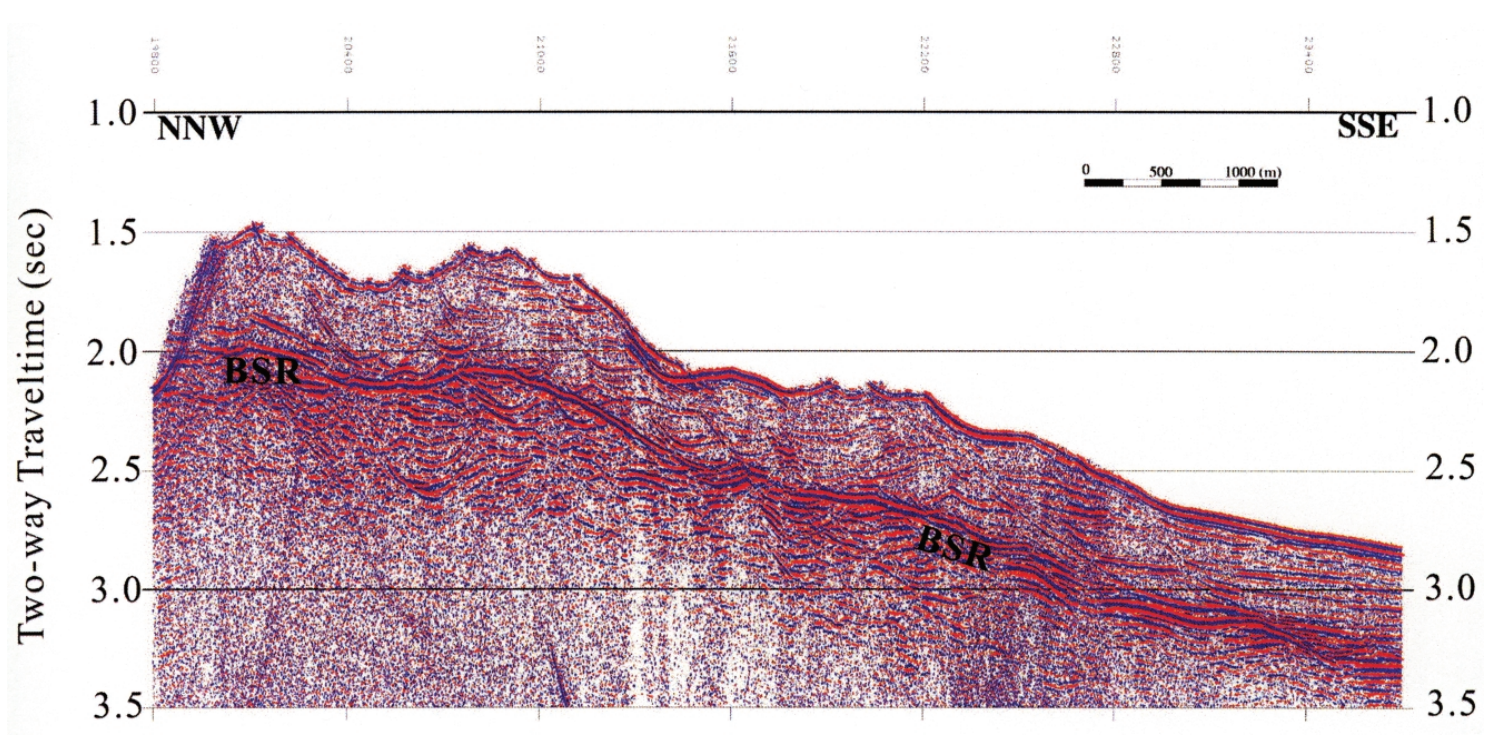

Fig. 11. Migrated seismic section MCS719-18. This profile runs along the axis of a slope ridge in the passive margin (see Fig. 4 for profile location). The BSR extends continuously under the ridge.

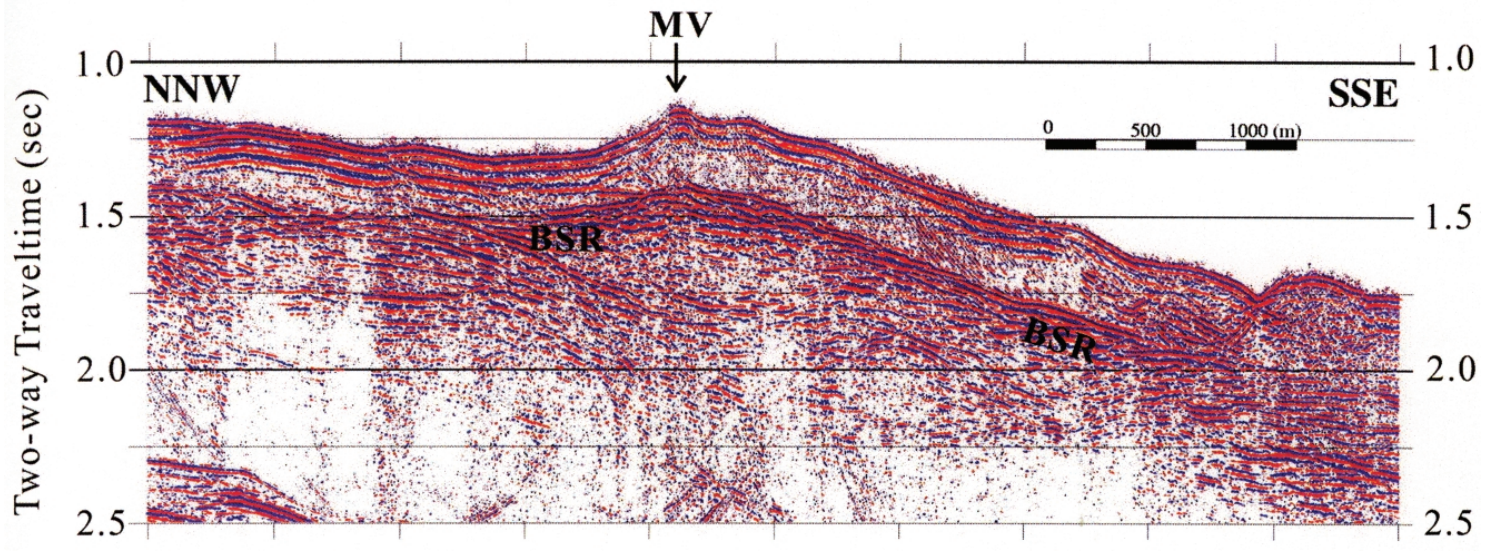

Fig. 12. Migrated seismic section MCS764-34. The BSR extends continuously under this lower slope ridge (see Fig. 4 for profile location) and a mud volcano (MV) is identified near the peak of the ridge. 


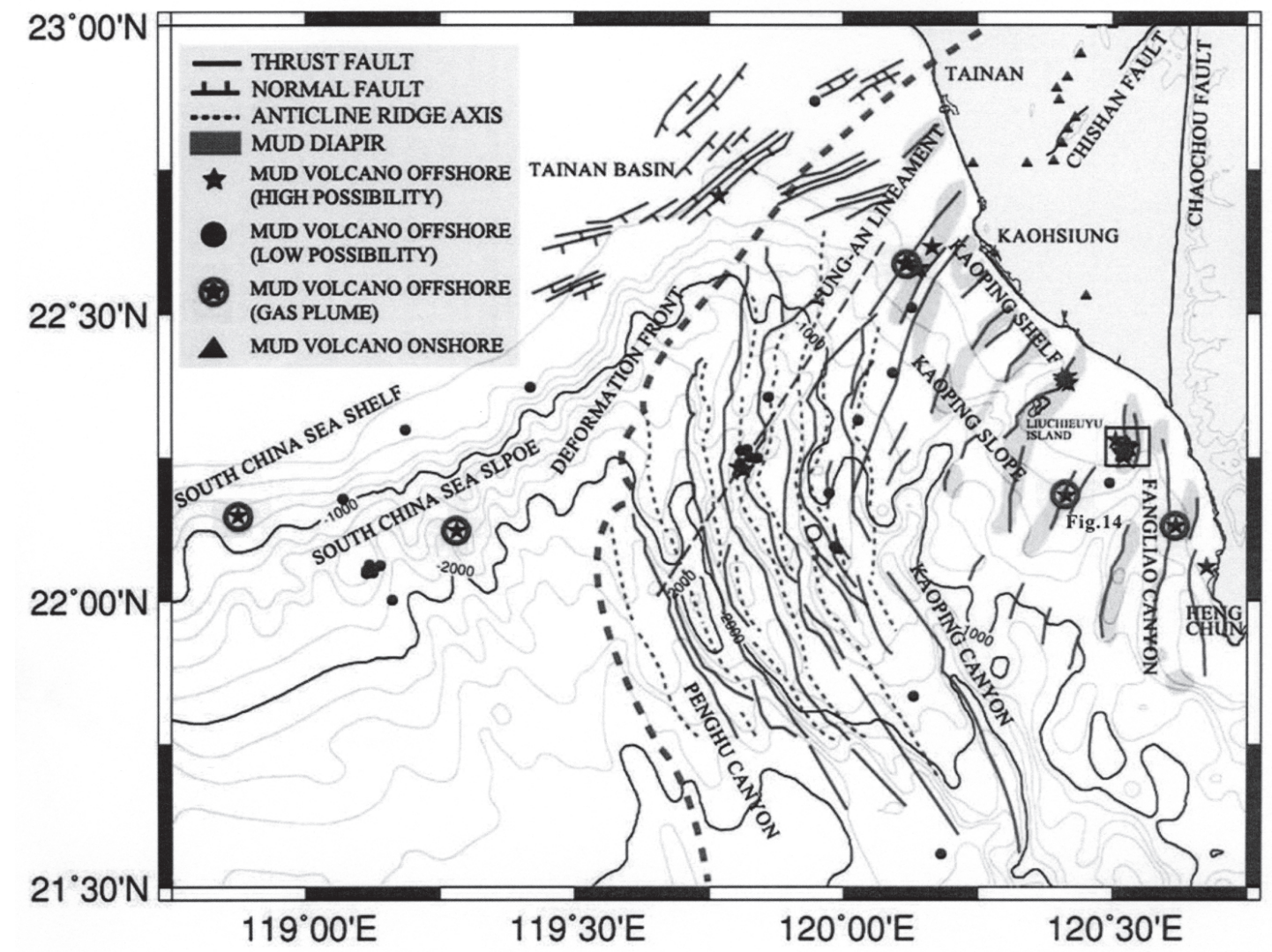

Fig. 13. Mud volcano distribution map onshore and offshore of SW Taiwan (modified from Chiu et al. 2006). Star with circle shows where gas plumes have been observed. The small box located near the northern end of the Fangliao Canyon is the place where a cluster (over 10) of mud volcanoes are observed. The sonar and seismic images of a mud volcano in the Kaoping slope area (labeled Fig. 14) are shown in Fig. 14.

high methane flux in this region. Figure 14 shows a submarine mud volcano in the upper Kaoping slope area where gas plume that rose about $76 \mathrm{~m}$ above seafloor has been observed on the $38 \mathrm{kHz}$ profile data. This mud volcano sits on top of a mud diapiric ridge (Figs. 13, 14). Methane concentrations in bottom sea water and in pore space of cored sediment at this site are extremely high (over 3 orders of magnitude higher than the background values) (T. F. Yang, personal communication). Yang et al. (2006) suggest that the active venting gases may share similar gas sources for on land mud volcanoes and gas hydrates off SW Taiwan. 

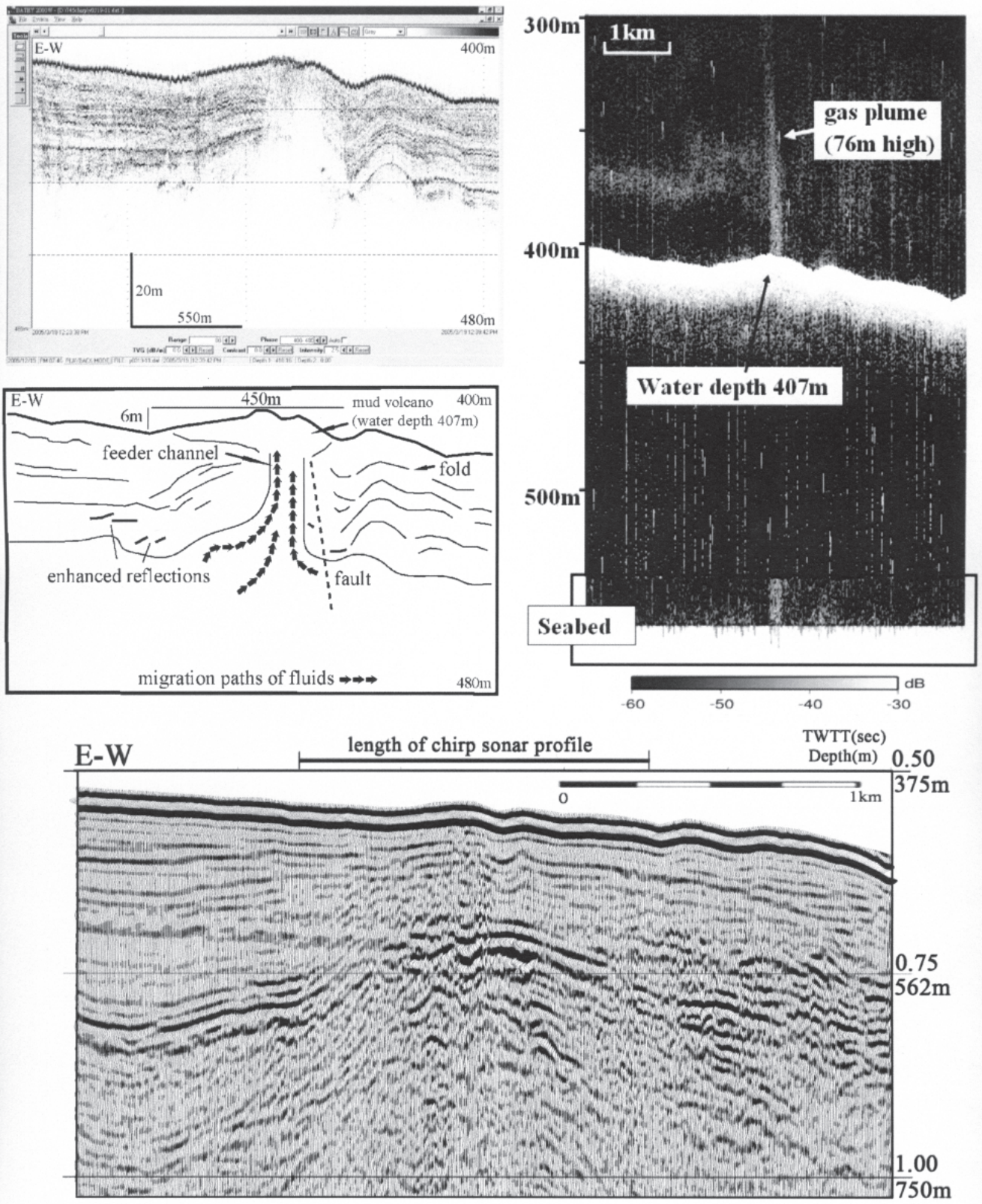

Fig. 14. An active mud volcano imaged by $38 \mathrm{kHz}$ echo sounder (upper right), chirp sonar (upper left) and multichannel seismic reflection profile (bottom). Gas plume can be seen clearly on the $38 \mathrm{kHz}$ profile, gas vent appears as white zone beneath mud volcano on the chirp sonar profile, while seismic profile reveals that there is a mud diapir lying below the mud volcano (bottom). Location of this mud volcano is given in Fig. 13. 
Besides temperature and pressure, fluid activity is also an important factor that governs the formation and dissociation of gas hydrate (e.g., Nimblett and Ruppel 2003). In the accretionary wedge setting, fluid migration paths are strongly controlled by structures. Careful examination of closely spaced seismic profiles could help us to observe various factors affecting gas hydrate emplacement. Schnürle and Liu (2006) has demonstrated the usage of a set of 2.5-D MCS dataset to establish a fluid migration model (Fig. 15).

Considering that advective fluid flow exceeds diffusive flow in the tectonically dewatering anticlinal ridge, and that fluid paths follow the bedding (assuming that no fault or fracture cuts through the bedding), then the maximum fluid transport across the BSR should occur below the crest of the ridge where the angle between the BSR and bedding is the largest. Strata that are sub-parallel to the BSR would give the least amount of fluid transport across BSR. Schnürle and Liu (2006) have calculated local dips and strikes of the BSR and the stratigraphic horizon that cross cuts the BSR at the intersections of any 2 seismic profiles. In the presence of high angle faults, the fault-plans instead of bedding horizons were used. Then a fluid migration model could be constructed by showing the direction (arrows show the up-dip directions of the sedimentary strata at the BSR) and fluid flow rate (expressed by the length of the arrow which was calculated by taking the sine of the difference between the dips of a stratum and the BSR). Figure 15 shows that in this 2.5-D survey box, the dominant fluid flow direction is $\mathrm{N} 308^{\circ}$ up-dip, which is parallel to the plate convergence direction. There are two places where long arrows are concentrated: one cluster of long arrows is on an anticlinal ridge located in the northwestern corner of the survey box where two piston cores, G23 and G24 were collected. The other cluster of long arrows covering a ridge located in the southern central part of the survey box where one piston core G22 was collected. Extremely high methane concentrations (Chuang et al. 2006) and very rapid sulfate reduction (Lin et al. 2006) have been observed from the bottom sea water and pore water, and core sample analyses at these two ridges, thus the geochemistry data are consistent with the fluid migration model from seismic investigation.

\section{DISCUSSION AND SUMMARY}

High-resolution seismic reflection data is well suited for mapping BSR. With the reconnaissance surveys conducted using a high-resolution MCS system, places where BSRs are densely distributed can be easily identified. However, the short-offset high-resolution MCS system cannot provide constraints on gas hydrate concentration in the sedimentary strata, largeoffset seismic reflection data and/or OBS data are needed to estimate the amount of gas hydrate or free gas in the sedimentary strata. Seismic velocity analyses from a large-offset seismic reflection dataset show that there are low velocity zones beneath BSRs under anticlinal ridges, suggesting free gases exist beneath hydrate-bearing sedimentary strata. There are active fluid activities in the investigation area. 2.5-D seismic data volume can provide details of the structure, stratigraphy and BSR variations, and use for fluid migration model construction. With detailed mapping of BSRs and their sub-bottom depths, we have estimated the heat flow values in the investigation area. The regional heat flow value estimated from water depth versus BSR sub-bottom depth relationship is about $50 \mathrm{~mW} \mathrm{~m}^{-2}$, with lower regional values in the China continental margin (near $40 \mathrm{~mW} \mathrm{~m}^{-2}$ ) and higher regional values in the accretionary 


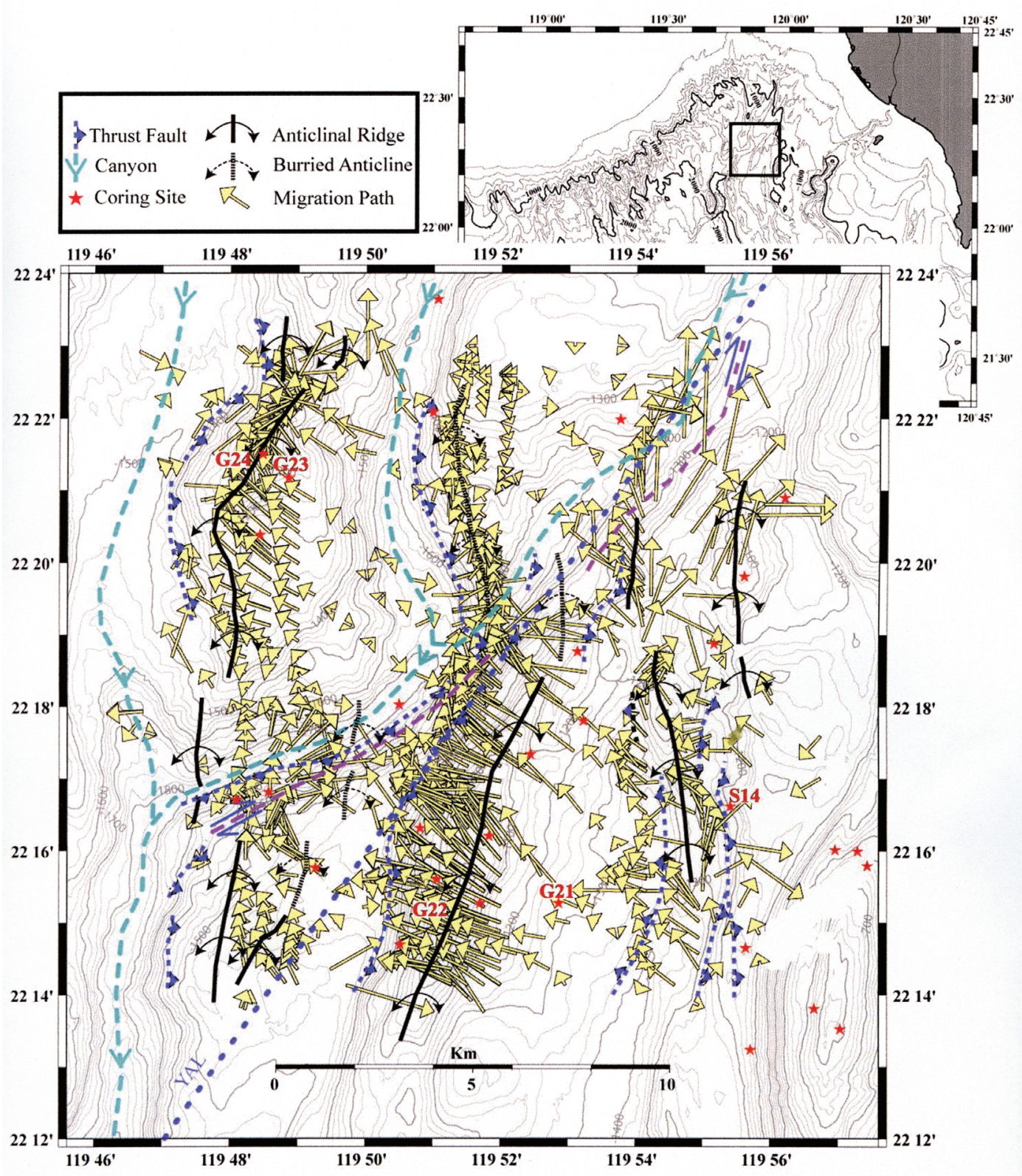

Fig. 15. Estimated preferential fluid migration paths across the BSR in one of the 2.5-D survey area (see box in the index map for location). The length of each arrow indicates the flow rate at that point. The meaning of different symbols are given in the small box above this figure. YAL (the dark blue dash line) is the Yung-An lineament which is a linear topographic feature and could be the surface expression of a transpressional fault (Liu et al. 2004). 
wedge province, reaching $60 \mathrm{~mW} \mathrm{~m}^{-2}$ near the Manila trench. These values are lower than that derived from seafloor heat flow measurements of Shyu et al. (2006) who used a different stability curve, and made corrections for sedimentation.

Gas hydrate has been found in both the convergent accretionary wedges and the extensional passive continental margins around the world. Offshore of SW Taiwan, these two distinctive tectonic provinces connect together, and gas hydrate spreads across both tectonic provinces. Most of the sediment in the accretionary wedge is derived from the Taiwan mountain belt, while most of the sediment in the China continental margin came from China. Both biogenic and thermogenic gases have been detected in the accretionary wedge province (Oung et al. 2006) off SW Taiwan, but up to now only biogenic gases have been found in the passive China continental margin province (T. F. Yang, personal communication). So with different tectonic settings, different sedimentary sources, different structural developments, yet continuous BSR distribution, the gas hydrate field off SW Taiwan will provide us a good opportunity to compare the sources, formation, migration paths and accumulation of gas hydrate in an accretionary wedge and a passive continental slope environment.

"Petroleum system" approach has been widely accepted as an essential procedure in gas hydrate investigation for energy resources. The gas hydrate field off SW Taiwan could be associated with known gas fields on the continental shelf (the F-field, presently under development by the Chinese Petroleum Company of Taiwan) and on land of southern Taiwan (the PCC and HSY fields). The F- and PCC-fields are normal fault-block traps that host thermogenic gas in Oligocene to Miocene sandstones (Lee et al. 1995), while the HSY field is a shallow, combined structural and stratigraphic trap that contains biogenic gas in Pleistocene sandstones (Fuh et al. 2005). The gas hydrate in the passive China continental slope may have the same petroleum system as the adjacent F-field (Fig. 1), and the shallow HSY field can provide an analog for the establishment of a gas hydrate field in the accretionary wedge.

In summary, MCS surveys reveal that BSRs are widely as well as densely distributed in both the accretionary wedge province and the passive China continental margin province offshore of SW Taiwan. Active fluid activities and venting systems in the investigation area have been observed using geophysical techniques (Chiu et al. 2006). Further evidence of gas vents came from seafloor photographs taken by a deep-tow camera system that show authigenic carbonates, carbonate mounds, chimney structures, and clam communities associated with bacterial mats on the sea floor where geochemical proxies for methane flux are high (S. Lin, personal communication). With all the geophysical data presented in this study, together with many geological observations (e.g., Jiang et al. 2006; Huang et al. 2006; Horng and Chen 2006) and geochemical analyses results (e.g., Lin et al. 2006; Chuang et al. 2006; Yang et al. 2006), we suggest that enormous amounts of gas hydrate should exist beneath the seafloor off SW Taiwan.

Acknowledgments We would like to thank Director C. C. Lin of the Central Geological Survey for the initiation and strong support of this gas hydrate investigation program. Captains and crew of the R/V Ocean Researcher I and Mr. S. D. Chiou of the Ocean Researcher I Precious Instrument Center are thanked for helping to collect the marine geophysical data. S. Y. Liu and K. R. Lai of the National Center for Ocean Research, J. K. Chiu, C. S. Chen, H. L. Chang, H. J. Chuang, W. H. Tseng, and many graduate students in the Exploration Seismol- 
ogy Lab of the Institute of Oceanography, National Taiwan University have participated in seismic cruises, and have prepared the bathymetry, sub-bottom profile and seismic reflection data and drafted many figures used in this paper. Discussions among gas hydrate team members are greatly appreciated, they being J. C. Chen, S. Lin, T. F. Yang, A. T. Lin, C. Y. Huang, C. S. Lee, T. K. Wang, W. B. Cheng, C. T. Shyu, H. S. Yu, S. K. Hsu, C. S. Horng, C. F. You, and W. T. Chiang. Comments and suggestions made by L. S. Teng and A. T. Lin greatly improve this paper. This study is supported by the Central Geological Survey grants 5226902000-06-93-01, 5226902000-05-94-01, and 5226902000-05-95-01.

\section{REFERENCES}

Bangs, N. L., D. S. Sawyer, and X. Golovchenko, 1993: Gree gas at the base of the gas hydrate zone in the vicinity of the Chile triple junction. Geology, 21, 905-908.

Best, A. I., M. D. Richardson, B. P. Boudreau, A. G. Judd, I. Leifer, A. P. Lyons, C. S. Martens, D. L. Orange, and S. J. Wheeler, 2006: Shallow seabed methane gas could pose coastal hazard. EOS Tran. AGU, 87, 213-217.

Bowin, C., R. Lu, C. S. Lee, and H. Shouten, 1978: Plate convergence and accretion in Taiwan-Luzon region. AAPG Bull., 62, 1645-1672.

Chang, C. H., 1993: Mud diapir investigation offshore southwestern Taiwan. Master Thesis, Natl. Taiwan Univ., Taiwan, 63 pp. (in Chinese)

Chao, H. C., and C. F. You, 2006: Distribution of B, Cl and their isotopes in pore waters separated from gas hydrate potential areas, offshore southwestern Taiwan. Terr. Atmos. Ocean. Sci., 17, 961-979.

Chen, M. P., and W. S. Juang, 1986: Seafloor physiography off southeastern Taiwan. Acta Oceanogr. Taiwan., 16, 1-17.

Chen, M. P., Y. T. Shieh, and C. S. Shyr, 1988: Seafloor physiography and surface sediments off southeastern Taiwan. Acta Geol. Taiwan., 26, 333-353.

Cheng, W. B., C. S. Lee, C. S. Liu, P. Schnürle, S. S. Lin, and H. R. Tsai, 2006: Velocity structure in marine sediments with gas hydrate reflectors in offshore SW Taiwan, from OBS data tomography. Terr. Atmos. Ocean. Sci., 17, 739-756.

Chi, W. C., D. L. Reed, C. S. Liu, and N. Lundberg, 1998: Distribution of the bottom-simulating reflector in the offshore Taiwan collision zone. Terr. Atmos. Ocean. Sci., 9, 779-794.

Chiang, C. H., H. S. Yu, and Y. W. Chou, 2004: Characteristics of the wedge-top depozone of the southern Taiwan foreland basin system. Basin Res., 16, 65-78.

Chiu, J. K., W. H. Tseng, and C. S. Liu, 2006: Distribution of gassy sediments and mud volcanoes offshore southwestern Taiwan. Terr. Atmos. Ocean. Sci., 17, 703-722.

Chow, J., J. S. Lee, R. Sun, C. S. Liu, and N. Lundberg, 2000: Characteristics of the bottom simulating reflectors near mud diapirs: Offshore southwestern Taiwan. Geo-Mar. Lett., 20, 3-9.

Chuang, H. J., 2006: Distribution and structural relationships of mud diapers offshore southwestern Taiwan. Master Thesis, Natl. Taiwan Univ., Taiwan, 113 pp. (in Chinese) 
Chuang, P. C., T. F. Yang, S. Lin, H. F. Lee, T. F. Lan, W. L. Hong, C. S. Liu, J. C. Chen, and Y. Wang, 2006: Extremely high methane concentration in bottom water and cored sediments from offshore southwestern Taiwan. Terr. Atmos. Ocean. Sci., 17, 903-920.

Collett, T., 2004: Gas hydrate as a future energy resources. Geotimes, November 2004, http:/ /www.agiweb.org/geotimes/nov04/feature futurehydrate.html.

Deregowski, 1990: Common offset migration and velocity analysis. Fist Break, 8, 225-234.

Dickens, G. R., 2004: Methane hydrate and abrupt climate change. Geotimes, November 2004, http://www.agiweb.org/geotimes/nov04/feature climate.html.

Dillion, W. P., J. W. Nealon, M. H. Taylor, M. W. Lee, R. M. Drury, and C. H. Anton, 2001: Seafloor collapse and methane venting associated with gas hydrate on the Blake Ridge - Causes and implications to seafloor stability and methane release. In: C. K. Paull, and W. P. Dillon (Eds.), Natural Gas Hydrates: Occurrence, Distribution, and Detection. Geophysical Monograph 124, AGU, Wash., D. C., 211-233.

Fuh, S. C., S. C. Liang, T. Z. Chang, S. H. Wu, and K. S. Chang, 2005: Biogenic gas potential associated with Plio-Pleistocene stratigraphic trap in southwestern Taiwan. J. Petrol., 41, 11-25. (in Chinese)

Fuh, S. C., C. S. Liu, N. Lundberg, and D. L. Reed, 1997: Strike-slip faults offshore southern Taiwan: Implications for the oblique arc-continent collision processes. Tectonophysics, 274, 25-40.

Gayet, P., C. Dicharry, G. Marion, A. Graciaa, J. Lachaise, and A. Nesterov, 2005: Experimental determination of methane hydrate dissociation curve up to $55 \mathrm{MPa}$ by using a small amount of surfactant as hydrate promoter. Chem. Eng. Sci., 60, 5751-5758.

Hamilton E. L., 1980: Geoacoustic modeling of the sea-floor. J. Acoust. Soc. Am., 68, 1313-1340.

Ho, C. S., 1986. A synthesis of the geological evolution of Taiwan. Tectonophysics, 125, 1-16.

Holbrook, W. S., H. Hoskins, W. T. Wood, R. A. Stephen, and D. Lizaralde, 1996: Methane hydrate and free gas volumes on the Blake Ridge from vertical seismic profiling. Science, 273, 1840-1843.

Horng, C. S., and K. H. Chen, 2006: Complicated magnetic mineral assemblages in marine sediments offshore of southwestern Taiwan: possible influence of methane flux on the early diagenetic process. Terr. Atmos. Ocean. Sci., 17, 1009-1026.

Hu, C. C., 1988: Basement structure and the Oligocene to Miocene stratigraphy of the Tainan Basin. Petrol. Geol. Taiwan, 24, 104-115. (in Chinese)

Huang, I. L., 1993: Structural analyses offshore southwestern Taiwan. Master Thesis, Natl. Taiwan Univ., Taiwan, 64 pp. (in Chinese)

Huang, W. L., 1995: Distribution of mud dispirs offshore of southwestern Taiwan and their relationships with the onshore structures and deposition environment. Master Thesis, Natl. Taiwan Univ., Taiwan, 68 pp. (in Chinese)

Huang, C. Y., C. W. Chien, M. Zhao, H. C. Li, and Y. Iizuka, 2006: Geological study of active cold seeps in the syn-collision accretionary prism Kaoping slope off SW Taiwan. Terr. Atmos. Ocean. Sci., 17, 679-702.

Huang, C. Y., C. T. Shyu, S. B. Lin, T. Q. Lee, and D. D. Sheu, 1992: Marine geology in the arc-continent collision zone off southeastern Taiwan: Implications for Late Neogene evolution of the Coastal Range. Mar. Geol., 107, 183-212. 
Huang, C. Y., W. Y. Wu, C. P. Chang, S. Tsao, P. B. Yuan, C. W. Lin, and K. Y. Xia, 1997: Tectonic evolution of accretionary prism in the arc-continent collision terrain of Taiwan. Tectonophysics, 281, 31-51.

Huang, C. Y., P. B. Yuan, C. W. Lin, T. K. Wang, and C. P. Chang, 2000: Geodynamic processes of Taiwan arc-continent collision and comparison with analogs in Timor, Papua New Guinea, Urals and Corsica. Tectonophysics, 325, 1-21.

Hyndman, R. D., J. P. Foucher, M. Y. Yamano, and A. Fisher, 1992: Deep sea bottom-simulating reflectors: calibration of the base of the hydrate stability field as used for heat flow estimates. Earth Planet. Sci. Lett., 109, 289-301.

Jiang, W. T., J. C. Chen, B. J. Huang, C. J. Chen, Y. T. Lee, P. R. Huang, C. C. Lung, and S. W. Huang, 2006: Mineralogy and physical properties of cored sediments from the gas hydrate potential area of offshore southwestern Taiwan. Terr. Atmos. Ocean. Sci., 17, 981-1007.

Johnson, A., and M. D. Max, 2006: The path to commercial hydrate gas production. The Leading Edge, 25, 648-651.

Kennett, J. P., K. G. Cannariato, I. L. Hendy, and R. J. Behl, 2003: Methane hydrates in Quaternary climate change: The clathrate gun hypothesis. Spec. Publ. Ser. Vol. 54, AGU, Wash., D. C.

Kvenvolden, K. A., 1988: Methane hydrates and global climate. Global Biogeochem. Cycles, 2, 221-229.

Kvenvolden, K. A., and T. D. Lorenson, 2001: The global occurrence of natural gas hydrate. In: C. K. Paull, and W. P. Dillon (Eds.), Natural gas hydrates- Occurrence, distribution and detection. Geophysical Monograph 124, AGU, Wash. D. C., 3-18.

Lee, C. I., J. N. Oung, A. H. Ke, L. H. Lin, T. Y. Chiou, and T. H. Huang, 1995: Petroleum system of the Tainan basin. Bull. Explor. Prod. Res. Chin. Petrol. Co., 18, 209-227. (in Chinese)

Lin, A. T., A. B. Watts, and S. P. Hesselbo, 2003: Cenozoic stratigraphy and subsidence history of the South China Sea in the Taiwan region. Basin Res., 15, 453-478.

Lin, S., W. C. Hsieh, Y. C. Lim, T. F. Yang, C. S. Liu, and Y. Wang, 2006: Methane migration and its influence on sulfate reduction in the Good Weather Ridge region, South China Sea continental margin sediments. Terr. Atmos. Ocean. Sci., 17, 883-902.

Liu, C. S., K. C. Chen, and P. Schnürle, 2003: Distribution and seismic characteristics of gas hydrate offshore southwestern Taiwan. EOS Trans. AGU, Fall Meet. Suppl., Abstract OS51C-0880.

Liu, C. S., B. Deffontaines, C. Y. Lu, and S. Lallemand, 2004: Deformation patterns of an accretionary wedge in the transition zone from subduction to collision offshore southwestern Taiwan. Mar. Geophys. Res., 25, 123-137.

Liu, C. S., I. L. Huang, and L. S. Teng, 1997: Structural features off southwestern Taiwan. Mar. Geol., 137, 305-319.

Liu, C. S., S. Y. Liu, S. E. Lallemand, N. Lundberg, and D. Reed, 1998: Digital elevation model offshore Taiwan and its Tectonic implications. Terr. Atmos. Ocean. Sci., 9, 705-738.

Liu, C. S., D. L. Reed, and N. Lundberg, 2000: Morphological and structural characteristics of a prominent out-of-sequence thrust offshore southwest Taiwan - an embryonic ana$\log$ to the seismogenic structure of the Chi-Chi earthquake? EOS Trans. AGU, 81, F1112. 
Liu, C. S., C. T. Shyu, P. Schnürle, S. Fuh, and T. H. Hsiuan, 1999: Exploration and analyses of gas hydrates offshore southwestern Taiwan. Proceedings Symposium on Exploration and Development of New Resources Offshore - Methane Hydrates. December 1999, Taipei, Taiwan. (in Chinese)

Lundberg, N., D. Reed, C. S. Liu, and J. Lieske, Jr., 1992: Structural controls on orogenic sedimentation, submarine Taiwan collision. Acta Geol. Taiwan., 30, 131-140.

Lundberg, N., D. L. Reed, C. S. Liu, and J. Lieske, Jr., 1997: Forearc-basin closure and arc accretion in the submarine suture zone south of Taiwan, Tectonophysics, 274, 5-24.

Malavieille, J., S. E. Lallemand, S. Dominguez, A. Deschamps, C. Y. Lu, C. S. Liu, P. Schnürle, and the ACT scientific crew, 2002: Geology of the arc-continent collision in Taiwan: marine observations and geodynamic model. In: Byrne, T., and C. S. Liu (Eds.), Geology and Geophysics of an Arc-Continent Collision, Taiwan, Geol. Soc. Am. Sp. Paper, 358, 187-211.

McDonnell, S. L., M. D. Max, N. Z. Cherkis, and M. F. Czarnecki, 2000: Tectono-sedimentary controls on the likelihood of gas hydrate occurrence near Taiwan. Mar. Petrol. Geol., 17, 929-936.

Nimblett, J., and C. Ruppel, 2003: Permeability evolution during the formation of gas hydrates in marine sediments. J. Geophys. Res., 108, 1-17.

Oung, J. N., C. Y. Lee, C. S. Lee, and C. L. Kuo, 2006: Geochemical study on hydrocarbon gases in seafloor sediments, southwestern offshore Taiwan - implications in the potential occurrence of gas hydrates. Terr. Atmos. Ocean. Sci., 17, 921-931.

Reed, D., N. Lundberg, C. S. Liu, and K. D. McIntosh, 1991: Evidence of frontal thrust propagation and fluid migration in an offscraped sedimentary basin sequence offshore Taiwan. TAICRUST Workshop Proceedings, Natl. Taiwan Univ., Taipei, Taiwan, 103-106.

Reed, D., N. Lundberg, C. S. Liu, and B. Y. Kuo, 1992: Structural relations along the margins of the offshore Taiwan accretionary wedge: implications for accretion and crustal kinematics. Acta Geol. Taiwan., 30, 105-122.

Schnürle P., and C. S. Liu, 2006: Structural controls on the formation of BSR offshore southwestern Taiwan from a 2.5-D seismic reflection survey. AAPG Memoir special issue on gas hydrates. (submitted)

Schnürle, P., D. H. Hsiuan, and C. S. Liu, 1999: Constrains on free gas and gas hydrate bearing sediments from multi-channel seismic data, offshore southwestern Taiwan. Petrol. Geol. Taiwan, 33, 21-42.

Schnürle, P., T. H. Hsiuan, T. K. Wang, K. McIntosh, C. S. Liu, D. Reed, and Y. Nakamura, 2002: Characteristics of gas hydrate and free gas offshore southwestern Taiwan: preliminary results from a combined seismic reflection/refraction analysis. Petrol. Geol. Taiwan, 35, 1-33.

Schnürle P., C. S. Liu, T. H. Hsiuan, and T. K. Wang, 2004: Characteristics of gas hydrate and free gas offshore southwestern Taiwan from a combined MCS/OBS data analysis. Mar. Geophys. Res., 25, 157-180.

Schnürle, P., C. S. Liu, and C. S. Lee, 2006: Acoustic and shear-wave velocities in hydratebearing sediments offshore southwestern Taiwan: tomography, converted waves analysis and reverse-time migration of OBS records. Terr. Atmos. Ocean. Sci., 17, 757-779.

Shipley, T. H., M. H. Houston, R. T. Buffler, F. J. Shaub, K. J. McMillen, J. W. Ladd, and J. 
L. Worzel, 1979: Seismic reflection evidence for widespread occurrence of possible gas-hydrate horizons on continental slopes and rises. AAPG Bull., 63, 2204-2213.

Shyu, C. T., Y. J. Chen, S. T. Chiang, and C. S. Liu, 2006: Heat flow measurements over bottom simulating reflectors, offshore southwestern Taiwan. Terr. Atmos. Ocean. Sci., 17, 845-869.

Shyu, C. T., S. K. Hsu, and C. S. Liu, 1998, Heat flows off southwest Taiwan: Measurements over mud diapirs and estimated from bottom simulating reflectors. Terr. Atmos. Ocean. Sci., 9, 795-812.

Singh, S. C., and T. Minschull, 1994: Velocity structure of a gas hydrate reflector at Ocean Drilling program site 889 from a global seismic waveform inversion. J. Geophys. Res., 99, 24221-24233.

Sloan, E. D., 1998: Clatherates hydrates of natural gases. Marcel Decker, New York, 641 pp.

Stoll, R. D., J. Ewing, and G. M. Bryan, 1971: Anomalous velocities in sediments containing gas hydrate. J. Geophys. Res., 76, 2090-2094.

Sun, S. C., 1982: The Tertiary basins of offshore Taiwan. Proc. $2^{\text {nd }}$ ASCOPE Conf. and Exhibition, 1981, Manila, Philippine, 125-135.

Sun, S. C., and C. S. Liu, 1993: Mud diapirs and submarine channel deposits in offshore Kaohsiung-Hengchun, southwest Taiwan. Petrol. Geol. Taiwan, 28, 1-14.

Teng, L. S., 1990. Late Cenozoic arc-continent collision in Taiwan. Tectonophysics, 183, 57-76.

Tucholke, B. F., G. M. Bryan, and J. I. Ewing, 1977: Gas-hydrate horizons detected in seismic-profiler data from the western North Atlantic. AAPG Bull., 61, 698-707.

Vanneste, M., M. de Batist, A. Golmshtok, A. Kremlev, and W. Versteeg, 2000: Multi-frequency seismic study of gas hydrate-bearing sediments in Lake Baikal, Siberia. Mar. Geol., 172, 1-21.

Wood, W. T., and C. Ruppel, 2000: Seismic and thermal investigations of the Blake ridge gas hydrate area: a synthesis. In: Paull, C. K. et al. (Eds.), Proceeding of the Ocean Drilling Program, Scientific Results, 164, 253-264.

Wood, W. T., P. L. Stoffa, and T. H. Shipley, 1994: Quantitative detection of methane trough high resolution seismic velocity analysis. J. Geophys. Res., 99, 9681-9695.

Yan, P., H. Deng, and H. Liu, 2006: The geological structure and prospect of gas hydrate over the Dongsha Slope, South China Sea. Terr. Atmos. Ocean. Sci., 17, 645-658.

Yang, K. M., H. H. Ting, and J. Yuan, 1991: Structural styles and tectonic modes of Neogene extensional tectonics in southwestern Taiwan: Implications for hydrocarbon exploration. Petrol. Geol. Taiwan, 26, 1-31.

Yang, T. F., P. C. Chuang, S. Lin, J. C. Chen, Y. Wang, and S. H. Chung, 2006: Methane venting in gas hydrate potential area offshore of SW Taiwan: evidence of gas analysis of water column samples. Terr. Atmos. Ocean. Sci., 17, 933-950.

Yang, T. F., G. H. Yeh, C. C. Fu, C. C. Wang, T. F. Lan, H. F. Lee, C. H. Chen, V. Walia, and Q. C. Sung, 2004: Composition and exhalation flux of gases from mud volcanoes in Taiwan. Environ. Geol., 46, 1003-1011.

Yen, J. Y., and N. Lundberg, 2006: Sediment compositions in offshore southern Taiwan and their relations to the source rocks in modern arc-continent collision zone. Mar. Geol., 225, 247-263. 
Yu, H. S., and Z. Y. Huang, 2006: Intraslope basin, seismic facies and sedimentary processes in the Kaoping slope, offshore southwestern Taiwan. Terr. Atmos. Ocean. Sci., 17, 659-677.

Yu, H. S., and Y. H. Wen, 1992: Physiographic characteristics of the continental margin off southwestern Taiwan. J. Geol. Soc. China, 35, 337-351.

Liu, C. S., P. Schnürle, Y. Wang, S. H. Chung, S. C. Chen, and T. H. Hsiuan, 2006: Distribution and characters of gas hydrate offshore of southwestern Taiwan. Terr. Atmos. Ocean. Sci., 17, 615-644. 